\title{
COMMENTS
}

\section{DOUBLE JEOPARDY: \\ THE MODERN DILEMMA FOR JUVENILE JUSTICE}

\author{
Christina L. ANDERSON ${ }^{\dagger}$
}

INTRODUCTION

Recent media reports focusing on specific, high-profile incidents of adolescent crime would have American society believe that juvenile violence rates have reached epidemic proportions. Magazine and newspaper editors brand today's teenagers "the most damaged and disturbed generation the country has ever produced" and perpetuate the myth of the adolescent "superpredator." Much of this media hype has centered its sensationalism around the violence occurring on school grounds. Particularly in the wake of the Columbine High School shootings, the public responded to its media-generated fear by demanding a "get-tough" policy for violence in schools. Though "zero tolerance" had been present before such events, politicians and school administrators found themselves increasingly familiarized with the term in the late 1990s.

In acknowledgment of the intensifying public pressure, school administrators began expanding the federal mandates surrounding

${ }^{\dagger}$ B.A. 2000, Villanova University; J.D. Candidate 2004, University of Pennsylvania. I would like to acknowledge my family and friends who have actively supported my enthusiasm for criminal justice reform. I would also like to extend special thanks to Dr. Lance Hannon for his guidance and careful consideration of my work; to the Forum on Restorative Community Justice and the School Mediation Center for their willingness to communicate about the current trends in community/family group conferencing; and to the University of Pennsylvania Law Review for helpful suggestions on earlier drafts of this Comment.

${ }^{1}$ Randall Sullivan, A Boy's Life, Part 2, Rolling Stone, Oct. 1, 1998, at 46, 50; see also Ronald W. Erickson, Don't Glorify Criminals, L.A. TIMEs (Orange County), July 19, 1998 , at B6 (characterizing violent youth as "moral degenerates").

${ }^{2}$ For the earliest use of this term, see John J. DiIulio, Jr., The Coming of the Superpredators, WKLY. STANDARD, Nov. 27, 1995, reprinted in John J. Dilulio, Jr., Moral Poverty, CHI. TRIB., Dec. 15, 1995, at 31, which describes the adolescent "superpredator" as a "morally impoverished juvenile ... capable of committing the most heinous acts of physical violence for the most trivial reasons." 
weapons policies to include a wider variety of behaviors and harsher sanctions. In addition, educational institutions began intertwining their disciplinary duties with those of law enforcement agents. Increasingly, police officers were called into schools to handle conflicts, and as a result, young students frequently found themselves faced with dual punishments, a "double jeopardy" of sorts: suspension/expulsion on one hand and criminal penalties on the other.

This concentration on severity as a way to deter juvenile violence has resulted in not only a lack of disciplinary alternatives for cases with mitigating circumstances, but also a lack of adequate support systems for the affected juveniles. As authorities increasingly relinquish responsibility by simply removing students from schools, these youth find themselves distanced from the exact social institutions charged with teaching them the conformist norms necessary to become successful citizens. This social disconnect not only isolates them from mainstream conformist voices, but also leaves them vulnerable to the call of deviant subcultures, thus encouraging further delinquency and disadvantage.

As the overwhelming majority of schools have already become entrenched in their zero-tolerance mentality and courts have consistently upheld such punitive measures, reform efforts aimed at reconnecting juveniles to the systems so readily discarding them must focus on implementing supplemental approaches to counterbalance the zerotolerance model. Restorative justice provides such counterbalance. This alternative justice system, which may be implemented through a number of formats, such as victim-offender mediation, community reparative boards, circle sentencing, or family group conferencing, employs a different framework than the traditional, retributive model. Instead of concentrating solely on consequences, restorative justice ideology looks to a broader range of concerns: the parties' relationships, voices, and social context. Restorative justice approaches lend victims, offenders, and community members the chance to congregate, communicate, and develop reasonable, mutually agreeable, reparative solutions. Specific to educational discipline, then, restorative justice practices can offset an absolutist, punitive trend by presenting both schools and communities with an opportunity to define their own versions of justice while, at the same time, providing a forum for the reintegration of deviant youth.

This Comment evaluates and exposes the realities of inflexible penalties for youth as well as unearths the spectrum of equitable alternatives to the "get-tough" model. To begin the exploration of 
this continuum, Part I focuses on the existing disciplinary system in the majority of states. Section A supplies a recent chronology of the zero-tolerance movement in schools and discusses the socio-political and legal factors which surround the zealous retributive trend. Section B examines the realities of school crime, questioning the appropriateness of mandatory suspension/expulsion measures in addressing the daily deviance of young students.

Part II then focuses on the simultaneous upsurge in the imposition of formal sanctions by the juvenile justice system. Sections A and $B$ assess how the disciplinary goals and tactics of educational facilities have begun to overlap with those of the juvenile justice system, creating a type of "dual enforcement" wherein the institutions share information, authority, and social functions. Section $\mathrm{C}$ documents the social and legal entrenchment of this pervasive, punitive mentality.

Part III, however, identifies a reasonable alternative to such hardnosed, retributive recourse: restorative justice. Section A first explains the general restorative theory, next references particular models for the implementation of restorative justice, and lastly, offers examples of successful, real-world applications. Section B details the benefits of supplementing harsh punishments with a more individualized and integrative forum. After summarizing the administrative, social, and personal advantages incurred through restorative justice practices, Section $B$ concludes with an emphasis on the critical potential for reintegration generated by such mechanisms and a report on restorative justice's recent success.

\section{ZERO-TOLERANCE POLICIES}

\section{A. The Recent Trend Toward Increased Punishment}

"Zero tolerance" has become a familiar and prevalent term in American parlance, connoting a "policy that mandates predetermined consequences or punishments for specific offenses." We often hear about lawmakers' "zero-tolerance" approaches to drug use and possession, but the term has carried particular significance with regard to school administrative strategies. School guidelines on weapons,

${ }^{3}$ Phillip Kaufman et al., U.S. Dep'T of Educ. \& U.S. DeP'T OF JUStice, INDICATORS OF SCHOOL CRIME AND SAFETY, 1999, at app. A at 117 (1999), available at http://www.ojp.usdoj.gov/bjs/pub/pdf/iscs99.pdf. 
while leaning toward "zero tolerance" prior to amplified media hype," significantly increased in both number and severity following the highly publicized school shootings that occurred during the late 1990s. " $[\mathrm{M}]$ andatory expulsion became the rule rather than the exception in matters of school discipline."

After the passage of the Gun-Free Schools Act of $1994,{ }^{7}$ all fifty states introduced zero-tolerance legislation. ${ }^{8}$ The Gun-Free Schools Act requires local educational agencies to mandate a one-year expulsion for students who bring weapons to school. ${ }^{9}$ Additionally, the Act mandates the referral of law-violating students to the criminal or juvenile justice systems. ${ }^{10}$ Congress has conditioned the receipt of certain federal funding on the implementation of this weapons mandate."

Currently, ninety-four percent of all public schools have executed at least one zero-tolerance policy. ${ }^{2}$ Furthermore, zero-tolerance policies now cover a wide range of behavior. Besides the most notable guidelines involving the possession of weapons, schools have

4 See Russell J. Skiba, Indiana Educ. Policy Citr., Zero Tolerance, Zero EVIDENCE: AN ANALYSIS OF SCHOOL DisCIPLINARY PRACTICE 2 (2000) (stating that zerotolerance policies had been widely adopted in the United States by 1993), available at http://www.indiana.edu/ safeschl/ztze.pdf; Bernadine Dohrn, "Look Out, Kid, It's Something You Did": The Criminalization of Children, in THE PUBLIC ASSAULT ON AMERICA'S CHILdREN: POVERTY, VIOLENCE, AND JUVENILE INJUSTICE 157, 162 (Valerie Polakow ed., 2000) (claiming that the momentum of zero-tolerance and security policies had been escalating prior to the high-profile school shootings).

${ }^{5}$ See Daniel Perlstein, Failing at Kindness: Why Fear of Violence Endangers Children, EDUC. LEADERSHIP, Mar. 2000, at 76, 76 (discussing the push for zero-tolerance punishment following school shootings).

${ }^{6}$ Sasha Polakow-Suransky, America's Least Wanted: Zero-Tolerance Policies and the Fate of Expelled Students, in THe Public Assault On AMERICA's ChILdREN, supra note 4, at 101, 103.

${ }^{7}$ Pub. L. No. 103-382, 108 Stat. 3907 (codified as amended at 20 U.S.C.S. $§ 7151$ (Law. Co-op. 2003) (original version at 20 U.S.C. $\$ 8921$ (2000))).

${ }^{8}$ See Polakow-Suransky, supra note 6 , at 103 ("Within one year of [the Gun-Free Schools Act's] enactment all 50 states had introduced zero-tolerance legislation .....).

920 U.S.C.S. $\$ 7151$ (b) (1).

${ }^{10} \$ 7151(\mathrm{~h})(1)$.

${ }^{11} \$ \$ 7151(\mathrm{~b})(\mathrm{1}),(\mathrm{h})(1)$; see also Zero-Tolerance Policies: Before the U.S. Commission on Civil Rights, (2000) (statement of Julie Underwood, General Counsel, Nat'l Sch. Bds. Ass' $\mathrm{n}$ ), restricted access at http://www.nsba.org/cosa/cosa_report.cfm?idfield=931\& (on file with author) (stating that funds received through the Elementary and Secondary Education Act are conditioned on compliance with the Gun-Free Schools Act).

${ }^{12}$ See Sheila Heaviside et Al., U.S. DeP'T OF Educ., Violence And Discipline Problems IN U.S. PUBliC SCHOOLS: 1996-97, at 83 tbl.19 (1998) (ascertaining that ninety-four percent of public schools had zero-tolerance policies in place for offenses related to firearms). 
implemented zero-tolerance-type policies pertaining to violence, ${ }^{13}$ bullying, ${ }^{14}$ threatening, ${ }^{15}$ the use of profanity, ${ }^{16}$ and alcohol/tobacco consumption. ${ }^{17}$ In addition, some schools have attempted to place strict punishments on those students engaging in ambiguously defined acts such as "intimidation." 18 Interestingly, then, even though the federal requirement was established to prevent the possession of weapons in school, from 1996 to 1997, 50,961 expulsions occurred as a result of fights; 30,522 as a result of an alcohol-, tobacco-, or drug-related offense; and only 18,841 as a result of weapon possession (broadly defined). ${ }^{19}$

Thus, educational institutions have extended zero-tolerance efforts considerably beyond the federal mandate established in the GunFree Schools Act. Furthermore, not only have schools incorporated a more diverse array of behaviors within their supervisory scope, but they have also gone beyond the required sanctions for such behaviors. Some schools have begun to experiment with permanent expulsion as

${ }^{13}$ See id. (noting that seventy-nine percent of schools had zero-tolerance policies relating to "violence"); see also Lisa Petrillo, 8-year-old May Be Expelled Under "ZeroTolerance" Code, SAN Diego UNion-Trib., Oct. 29, 1997, at B-1 (describing a zerotolerance policy applicable to fighting on school grounds).

${ }^{14}$ See, e.g., D.L. Bennett \& Mark Bixler, Bully Legislation Pushes Through, AtLanTa J.CoNST., Apr. 1, 1999, at JQ10 (detailing the impetus for and contents of new bully legislation in Georgia).

${ }^{15}$ See, e.g., Alan J. Borsuk, Idle or Otherwise, Threats Bring Severe Discipline: Where Area Students Once Faced a Principal, Now They Face the Police, MilwaukeE J. Sentinel, Apr. 30, 1999, at 8A (addressing numerous suspensions for threats made in the wake of Columbine).

${ }^{16}$ See, e.g., Sally Falk Nancrede, School to Take Foul Mouths to Task, INDIANAPOLIS STAR, Aug. 20, 1998, at Al (describing a local zero-tolerance policy aimed at punishing students for swearing on school grounds).

${ }^{17}$ See HEAvISIDE ET AL., supra note 12, at 83 tbl.19 (indicating that eighty-seven percent of public schools had implemented zero-tolerance measures with regard to alcohol, and eighty-eight percent and seventy-nine percent had done the same for drugs and tobacco, respectively); see also Anita Kumar, Suit Fights School Alcohol Policy, St. Petersburg Times (Florida), Dec. 28, 1999, at 3B (discussing a school's zerotolerance policy that invoked automatic suspension and reassignment for any student caught with alcohol at school or at a school-sponsored event).

${ }^{18}$ Columbine High School, for example, has instituted a policy of "zero tolerance" for "cruelty, harassment, excessive teasing, discrimination, violence, and intimidation." Tom Kenworthy, At Columbine, Rally Skips Remembrance, WASH. POST, Aug. 17, 1999, at A3.

${ }^{19}$ JILL F. DEVOE ET AL., U.S. DEP'T OF EDUC. \& U.S. DEP'T OF JUSTICE, INDICATORS OF SCHOOL CRIME AND SAFETY: 2002, at app. A at 142 tbl.A6 (2002) (citing NAT'L CTR. FOR EdUC. STATISTICS, U.S. DeP'T OF EdUC., PRINCIPAL/SCHOOL DisciplinaRIaN SURVEY ON SCHOOL VIOLENCE (1997), available at http://www.ojp.usdoj.gov/bjs/pub/ pdf/iscs02.pdf). 
opposed to the mandated minimum of a one-year expulsion. ${ }^{20}$ Even more drastic, a couple of states now require permanent expulsion in certain circumstances."

This exponential growth of zero tolerance has even affected the very youngest students. Minneapolis schools have suspended more than 500 kindergarteners in the last two years for varying levels of misconduct; $^{22}$ schools in Greenville, South Carolina, suspended 132 firstgraders as well as 75 kindergarteners during the 2001-2002 school year; ${ }^{23}$ and Philadelphia schools suspended 33 kindergarteners in one quarter alone (fall 2002). ${ }^{24}$ The rather shocking amount of suspensions for primary school attendees has been connected to school administrators' drive for compliance with their zero-tolerance policies. ${ }^{25}$ These statistics provided fodder for sensationalists, who rushed to broadcast them and label these children, just as they did older students following incidents such as the Columbine shootings. A recent news article, immediately headlined on television news stations, termed the children "kamikaze kindergarteners." ${ }^{26}$

${ }^{20}$ See, e.g., Cleveland School District Updates, CATAlyST: FOR CLEVELAND Schools, Sept./Oct. 1999 (reporting that, in a "major overhaul" of their discipline policies, Cleveland schools allowed for permanent expulsion in cases involving threats or the possession of weapons), available at http://www.catalyst-cleveland.org/inaugural/ updates.htm; Stephen Henderson, Groups Critical of "No Second Chances" School Proposal, BALT. SUN, Jan. 27, 1999, at 4B (evaluating the criticisms of a zero-tolerance measure implemented by Baltimore schools that authorized permanent expulsion for students violating school policies); Jennifer Smith Richards, Students Who Assaulted Teacher Face Charges, Expulsion, SAVANNAH MORNING NEwS, Nov. 8, 2003, at 1A (describing the recent classroom assault of a Savannah, Georgia, teacher and stressing that " $[\mathrm{s}]$ chool officials are pushing for permanent expulsion"), available at http://www.savannahnow. com/stories/110803/LOC_teacherassault.shtml.

${ }^{21}$ See, e.g., MicH. CoMP. LAWS ANN. $\$ 380.1311$ (West 1997) (requiring permanent expulsion for any student who possesses a dangerous weapon or commits either arson or rape on school grounds); NEV. REv. STAT. ANN. \$ 392.466(2) (Michie 2002) (stating that permanent expulsion from school must occur for a second weapons offense but that an expelled student may be required to receive equivalent instruction).

${ }_{22}$ Greg Toppo, School Violence Hits Lower Grades, USA TODAY, Jan. 13, 2003, at 2.

${ }^{23}$ Id.

${ }^{24}$ Susan Snyder, Suspensions Rise for Phila.'s Kindergartners, PHILA. INQUIRER, Dec. 13, 2002, at A1.

${ }^{25}$ See, e.g., id. (tying the wave of suspensions to principals' desire to comply with the district's zero-tolerance policy).

${ }^{26}$ Claudia Wallis, Does Kindergarten Need Cops?, TIME, Dec. 15, 2003, at 52, 53. Television news stations found the release of this article quite convenient for grabbing the attention of their viewers. For example, a Philadelphia television station broke to commercial requesting that the viewer stay tuned for information on the "growing problem of kindergarten rage." NBC 10 News at 5 p.m. (NBC television broadcast, Dec. 10,2003 ). 
In order to prevent the unnecessary inflation of penalties, the Gun-Free Schools Act specifically allows for administrative officials' discretion and case-by-case analysis when determining a student's punishment. $^{27}$ However, schools have often disregarded this provision, preferring blanket enforcement over individual assessments. ${ }^{28}$ While qualitative evidence appears to serve as the only current measurement of this phenomenon, such stories abound. Newspapers have reported a number of high-profile, zero-tolerance cases in which extreme, nondiscretionary enforcement was evident. For example, in Pensacola, Florida, a principal recommended expulsion for a teenage girl who brought nail clippers to school; ${ }^{29}$ in East Lake, Florida, a high school senior was suspended for the remainder of the academic semester after taking a sip of sangria at a luncheon for a school-sponsored internship; $;^{30}$ in Ewing, New Jersey, a young male was suspended for refusing to visit the school nurse; ${ }^{31}$ and in Waldorf, Maryland, a high school sophomore received a ten-day suspension for proclaiming that his French teacher was not fluent in the language. ${ }^{32}$

By placing "zero tolerance" in our everyday parlance and desensitizing Americans with regard to the harshness of the resulting punishments, each of these examples has further legitimized the implementation of zero-tolerance policies. Though some media reports continue to criticize the zero-tolerance methodology, the regularity with which the average American confronts the practice creates an ever-growing familiarity with the sanction's role in school discipline. This familiarity ultimately causes the average American to placidly embrace ideals of severity and inflexibility while concurrently reinforcing the notion that politicians and school administrators should continue promoting the widespread use of such tactics. A

2720 U.S.C.S. $\$ 7151$ (b) (1) (Law. Co-op. 2003).

${ }^{28}$ See advancement Project \& The Civil Rights Project, Harvard Univ., OpPortunities SusPended: THE Devastating CONSEQuences of Zero TOlERANCE AND SCHOOL DISCIPLINE POLICIES, at v (2000) [hereinafter OPPORTUNITIES SUSPENDED] ("Principals and administrators are no longer ... willing to use the discretionary clauses...."), available at http://www.civilrightsproject.harvard.edu/research/disci pline/call_opport.php?Page=3.

${ }^{29}$ Daniel Ruth, Zero Tolerance for Zero Tolerance, TAMPA TRIB., June 7, 1999, at 2.

${ }^{30}$ Edie Gross, Teachers Help Suspended Girl, ST. PeTERSBurg TimeS (Florida), Nov. 5, 1998, at 1B. District officials maintained the young woman's lengthy suspension even after receiving complaints from multiple community members. Id.

${ }^{31}$ Student Suspended for Refusing to See Nurse, N.Y. TIMES, Feb. 13, 1999, at B6.

32 Beth Berselli, Student Apologizes for Remark, Returns; Westlake Sophomore's Parents Say 10-day Suspension Too Severe a Response, WASH. POST, Feb. 28, 1999, at M3. The school perceived the juvenile's remark to be a "verbal attack." Id. 
more gradual and subtle consequence of this universal acceptance appears to be a mounting collective fear of violent teenagers and an exacerbated "demonization" of youth.

\section{B. The Reality of School Discipline}

The actual statistics clearly represent a different picture from that developed by the media frenzy. In reality, the shootings and violent gang fights that have received sensational coverage occur relatively infrequently when compared to the nonviolent crimes. "In both 199091 and 1996-97, the three discipline issues most frequently rated as serious or moderate problems by principals were student tardiness, student absenteeism or class cutting, and physical conflicts among students." ${ }^{35}$ While one may focus on the final category as support for the zero-tolerance approach, a 2002 survey specified the statistical significance of these categories, severely weakening zero-tolerance advocates' ability to assert such an argument: about thirty percent of public school principals reported that student tardiness and absenteeism were "serious or moderate problems" as opposed to the only one percent of principals reporting the same concern for students' possession of weapons. ${ }^{36}$

Thus, school districts, which hurried to adopt zero-tolerance policies in response to national perceptions of unabated youth violence, have responded to the wrong problem and, as a result, have neglected to address their primary discipline problems. Or have they? As discussed above, administrators continue to expand zero-tolerance policies. Consequently, the methods of zero tolerance have become a model approach for discipline generally, rather than a specific solution for violent crime. Now, even tardiness may fall within the parameters of a jurisdiction's zero-tolerance strategy. ${ }^{37}$ The more

${ }^{33}$ Dohrn, supra note 4, at 181.

${ }^{34}$ See HEAVISIDE ET AL., supra note 12, at $\mathrm{v}$ (noting that nonviolent crimes were eighteen times more likely to occur in schools than violent crimes). From 1996 to 1997, while only ten percent of schools reported an incident of serious, violent crime, forty-seven percent of schools documented an incident of the less serious or nonviolent sort. DEVOE ET AL., supra note 19, at viii.

${ }^{35}$ HEAVISIDE ET AL., supra note 12, at vi.

${ }^{30}$ DEVOE ET AL., supra note 19 , at $\mathbf{x}$.

37 See ARIZ. REv. STAT. ANN. \$ 15-841(B) (West 2002) (codifying the availability of expulsion as a disciplinary measure for "excessive absenteeism" on the part of students who have "either reached the age or completed the grade after which school attendance is not required"); LA. REV. STAT. ANN. $\$ 17: 416$ (3)(a) (xvi) (West 2001) (allowing a school principal to suspend "any pupil who... [i]s habitually tardy or 
appropriate question, then, is whether school districts have neglected to effectively address their primary discipline concerns.

\section{Is Suspension Successful?}

Once juveniles violate a code of conduct governed by zerotolerance processes, the preferred sanction has been suspension. ${ }^{38}$ For example, 87,000 children were expelled in 1998, on top of the more than 3.1 million who were suspended. ${ }^{39}$ This figure represents a "dramatic increase" in the use of a suspension-based protocol. ${ }^{40}$ Suspension, though a serious punishment, has been utilized for a wide variety of incidents, ranging from physical aggression and fighting to disrespect and attendance problems. ${ }^{41}$ Nevertheless, the success of this disciplinary response remains unclear. ${ }^{42}$ At best, strict

absent"); Cindy Morgan-D'Atrio et al., Toward Prescriptive Alternatives to Suspensions: A Preliminary Evaluation, 21 BEHAV. DISORDERS 190, 192 tbl.1 (1996) (presenting a 19931994 study of middle and high school students which found that fifty-three percent of suspensions resulted from inadequate attendance). But see Op. Att'y Gen. No. I78-242 (Ariz. 1978) (maintaining that a student may not be suspended or expelled from school on account of habitual absenteeism).

${ }^{38}$ See SkIBA, supra note 4, at 10 (denoting school exclusion as the "cornerstone of zero tolerance" and remarking that suspension, in particular, remains "among the most widely used disciplinary techniques").

${ }^{39}$ See OFFICE FOR CIVIL RightS, U.S. DEP'T OF EDUC., FALl 1998 ELEMENTARY AND SECONDARY SCHOOL CIVIL RightS COMPLIANCE REPORT: NATIONAL AND STATE ProJECTIONS 1 (2000) (addressing the number of students suspended or expelled in 1998); see also DEVOE ET AL., supra note 19, at app. A at 142 tbl.A6 (determining that 217,627 out-of-school suspensions (lasting five days or more) occurred as a result of fights; 105,723 as a result of an alcohol-, tobacco-, or drug-related offense; and 40,114 as a result of weapon possession (broadly defined) (citing NAT'L CTR. FOR EDUC. STATISTICS, supra note 19)).

${ }^{40}$ BRIAN BUmbarger, UNIV. ChILdREN'S POlicy P'SHIP, SCHOOl VIOLENCE: DisciplinaRY EXClUSION, PREVENTION AND ALTERNATIVES 2 (1999).

${ }^{41}$ See Morgan-D'Atrio et al., supra note 37, at 192 tbl.1 (finding that suspension is used as a consequence for inadequate attendance and classroom disruption); Russell J. Skiba et al., Office Referrals and Suspension: Disciplinary Intervention in Middle Schools, 20 EDUC. \& TREATMENT CHILD. 295, 296 (1997) (suggesting that suspension is commonly employed when students have been fighting, disobedient, or disrespectful).

${ }^{42}$ For example, while some commentators claim that a decrease in suspensions/expulsions proves effective policy, others make a similar claim for increases in suspension/expulsion rates. Compare Jessica Crosby, "Zero Tolerance" Makes its Mark, ORANGE COUNTY REg. (California), Dec. 18, 1994, at Al (noting that, after a threefold increase in county expulsions, some school districts have allowed principals discretion to recommend against expulsion), with Larry Barszewski, Weapons at School on Decline; New Figures Show Tough Policy Works, Sun-SENTINEL (Fort Lauderdale, Florida), Nov. 18, 1997, at 1A (postulating that the number of weapons seized in Palm Beach County, Florida, schools fell to a six-year low because of "tough penalties"), and C. Ginsberg \& L. Loffredo, Violence-Related Attitudes and Behaviors of High School Students-New York City, 
consequences could cause juveniles to choose conformist behaviors; at worst, these punishments could push youth away from support systems and aggravate existing aggressions. One study on the effects of punishment found that harsh repercussions were equally likely to lead to either result. ${ }^{43}$

With specific regard to "at-risk" youth, ${ }^{44}$ however, the data appear more concrete. For this population, "it seems unlikely that school suspension will successfully impact behavior." ${ }^{45}$ Once suspended, those juveniles already prone to nonconformist conduct will be further dissociated from traditional social institutions and extensive adult supervision. They may take exclusionary discipline to mean that school personnel do not desire their presence or that attendance is not important. ${ }^{46}$ In addition, these suspended youth may have more opportunity to congregate with other deviant peers. ${ }^{47}$

From a more comprehensive analysis, school suspension has been linked to an increase in the likelihood that a student will drop out of school. ${ }^{48}$ Though the cause of this correlation may be multifold, some researchers postulate that a counterreaction to punishment-based

1992, 42 MORBIDITY \& MORTALITY WKLY. REP. 773 (1993) (documenting how a metaldetector program decreased the number of weapons carried in schools), available at http://www.cdc.gov/mmwr/preview/mmwrhtml/00022011.htm.

${ }^{43}$ See Ron Van Houten, Punishment: From the Animal Laboratory to the Applied Setting, in THE EFFECTS OF PUNISHMENT ON HuMAN BeHAVIOR 13, $19-22$ (Saul Axelrod \& Jack Apsche eds., 1983) (asserting that severe punishment may cause either "suppression" or "escape").

"See SKIBA, supra note 4, at 13 (describing "at-risk" youth as those adolescents who "exhibit disnuptive behavior and social and academic deficits that leave them increasingly alienated from teachers and peers").

Id . at 14.

${ }^{46}$ See BeVerley H. Johns \& John P. Keenan, Techniques for Managing a SAFE SCHOOL 131 (1997) ("Suspension and expulsion send a clear message to students that they are not wanted in the school and allow students to escape from their problems.").

${ }^{47}$ See SKIBA, supra note 4, at 14 (recognizing that suspension may actually "accelerate" delinquency by removing structured supervision and allowing suspended students to socialize with one another).

48 See id. at 13 (noting that suspension may consciously be used by administrators as a "tool to encourage low-achieving students and those viewed as 'troublemakers' to leave school before graduation"); Ruth B. Ekstrom et al., Who Drops Out of High School and Why?: Findings from a National Study, 87 TCHRS. C. REc. 356, 360 tbl.1 (1986) (exhibiting that thirty-one percent of the dropout population had previously been suspended while only ten percent of the students who stayed in school had previously been suspended); Gary G. Wehlage \& Robert A. Rutter, Dropping Out: How Much Do Schools Contribute to the Problem?, 87 TCHRS. C. REC. 374, 380 (1986) (presenting evidence that discipline problems were a significant predictor of eventual "dropout," even though deviant youth also had fairly high expectations about future schooling). 
approaches is actually typical and may escalate deviance. ${ }^{49}$ A characteristic counterreaction to punitive authority in the school setting is a withdrawal of interest from the standards of the school. ${ }^{50}$ Once a juvenile's attachment to school norms deteriorates, a greater likelihood of deviant behavior exists. ${ }^{51}$ And, in a retributive culture, a deviant youth is not likely to remain in a mainstream school setting for long; "zero tolerance will eat him alive."

\section{Net Widening}

If educational institutions are now extending formal sanctions to a greater number of students, some juveniles are being labeled "deviant" where they previously would not have been. This result implicates the concept of "net widening," a term often used to describe the condition incurred when the most severe crimes are already being punished as harshly as possible but the legislative trend continues to increase the severity of punishment generally. Ultimately, this condition causes increased punishments for the less serious offenders since the punishments for the serious offenders already have reached a maximum. $^{53}$

49 See Richard E. Shores et al., Classroom Management Strategies: Are They Setting Events for Coercion?, 18 BEHAV. DISORDERS 92, 93 (1993) (positing that "coercive interactions" increase "aversiveness").

${ }^{50}$ See John BraithwaIte, Crime, Shame AND ReINTEgRation 32-33 (1989) (claiming that the withdrawal of interest from school standards is, in fact, typical of delinquent youth).

${ }^{51}$ Weak attachments to school are associated with delinquency. See, e.g., Robert Agnew, A Revised Strain Theory of Delinquency, 64 SOC. FoRCES 151, 161 (1985) (alleging that adolescents who find themselves in "aversive environments" are more likely to engage in delinquent behavior); Howard B. Kaplan \& Cynthia Robbins, Testing a General Theory of Deviant Behavior in Longitudinal Perspective, in PROSPECTIVE STUDIES OF CRIME AND DELINQUENCY 117, 138 (Katherine Teilmann Van Dusen \& Sarnoff A. Mednick eds., 1983) ("By far the most consistent predictor of subsequent deviant responses ... was felt rejection by the school.").

Conversely, when school environments foster a sense of "connectedness," significant positive outcomes emerge such as decreased occurrences of violence, drug/ alcohol use, and teen pregnancy. Clea A. McNeely et al., Promoting School Connectedness: Evidence from the National Longitudinal Study of Adolescent Health, J. SCH. HFALTH, Apr. 2002 , at $138,138$.

${ }_{52}$ Sonja Steptoe, Taking the Alternate Route, TIME, Jan. 13, 2003, at 50, 51 (quoting Cathleen Corella).

${ }^{59}$ The concept of "net widening" was first explored by Thomas G. Blomberg in his article, Widening the Net: An Anomaly in the Evaluation of Diversion Programs, in HANDBOOK OF CRIMINAL Justice Evaluation 572, 573-84 (Malcolm W. Klein \& Katherine S. Teilmann eds., 1980). 
Net widening appears to have particular application to today's zero-tolerance phenomenon. Suspensions and expulsions have "exploded" in recent years. ${ }^{54}$ However, contrary to media implications, most suspensions are dispensed for minor noncompliance or disrespect, ${ }^{j, 5}$ as indicated by the ninety percent of principals who report an absence of serious, violent crime in their schools. ${ }^{56}$ Moreover, a significant number of expulsions occur as a result of alcohol-, tobacco-, or drug-related offenses, rather than violent crimes. ${ }^{57}$ In fact, not only is violent crime a rarity in American schools, but even the rate of violence has begun to decline. "Between 1992 and 2000, there was a 46 percent decrease in the violent crime victimization rate at school...., ${ }^{58}$ Thus, the severity of punishments has increased (perhaps partly because of the media's attention to dramatic, rare cases) when the true threat of youth violence at school has actually diminished. While one may claim that zero-tolerance practices prove responsible for the decrease in violent crime, little empirical evidence exists to support this proposition. ${ }^{59}$ In fact, the few attempts at substantiating this claim have reached contradictory conclusions. ${ }^{60}$

Furthermore, the increase in formal punishments appears to have had a greater impact on those students who had previously been dealt with informally, the non-serious offenders. The new "crack-down" on school discipline has diverted a larger number of students into the punitive system, rather than away from it. When more individuals are exposed to forms of social control than otherwise would be under traditional sanctions, a net widening problem develops. ${ }^{61}$ Most "low-risk offenders" will succeed and maintain substantially conformist behaviors without intervention. ${ }^{62}$ Therefore, extensive efforts to address low-grade disobedience appear not only administratively wasteful, but

${ }^{54}$ Dohrn, supra note 4, at 165; see also sources cited supra notes $38-41$ (describing the increased and pervasive use of suspension as a punishment).

${ }^{55}$ Skiba et al., supra note 41 , at 309.

${ }^{56}$ See HEAvISIDE ET AL., supra note 12, at iv (observing that only ten percent of all public schools experienced a serious, violent crime during 1996-1997); see also supra notes 34-36 and accompanying text (exposing the rarity of violent crime in public schools).

${ }_{57}$ Supra text accompanying note 19.

${ }^{58}$ DEVOE ET AL., supra note 19 , at viii.

${ }^{59}$ SkIBA, supra note 4 , at 12-13.

${ }^{60}$ See sources cited supra note 42 (presenting evidence that zero tolerance has been touted for both decreasing and increasing school crime rates).

${ }^{6}$ Samuel Walker, Sense and Nonsense About Crime and Drugs: A Policy GulDE 209 (4th ed. 1998).

${ }^{62} I d$. 
also futile in successfully deterring critical populations. ${ }^{63}$ More importantly, punishment for non-serious offenses may, in fact, be harmful for those students who could be redirected through informal methods. Not only might net widening increase the average juvenile's association with other delinquents, but it may additionally cause otherwise compliant youth to dissociate from social networks and norms, ${ }^{64}$ thereby increasing the risk of subsequent deviant conduct. ${ }^{65}$

\section{Lack of Educational Alternatives for the Suspended/Expelled}

What happens to juveniles upon expulsion or suspension from school? Are the psychological and sociological ramifications the chief concerns? Research supports the notion that zero-tolerance practices produce significant negative academic consequences as well. In most instances, students who have been suspended "receive failing grades or do not have opportunities to make up missed schoolwork. They

${ }^{63}$ See BUMBARGER, supra note 40 , at 2 (noting that the overuse of suspension and expulsion has weakened their deterrent effects).

${ }^{64}$ See David M. Downes, The Delinglent Solution: A Study in Subcultural THEORY 236-41 (1966) (exploring the concept of "dissociation").

${ }^{65}$ Youth who have received official, or formal, punishment prove more likely to "endorse[] anti-establishment opinions" and exhibit "antisocial tendenc[ies]." D.J. WEST \& D.P. FARRINGTON, THE DELINQUENT WAY OF LIFE 158 (1977). In particular, such juveniles often disengage from familial relationships. See id. ("Reports of conflicts with parents, and an expressed preference for living away from the parental home, were common among the delinquents."). As mentioned above, supra note 50 and accompanying text, school attachments also suffer in the wake of formal punishments. Furthermore, these "anti-establishment" attitudes may lead to a decreased investment in other social institutions, such as businesses, the community, or the government. For instance, previously convicted deviants remain unemployed or in jobs offering limited opportunity for advancement more often than their non-convicted counterparts. WEST \& FARRINGTON, supra, at 158.

An anti-establishment trend, though, proves particularly dangerous as social institutions "provide order, meaning, [and] purpose" to individuals' lives. STEVEN F. MESSNer \& Richard ROSENFEld, CRIME AND THE AMERICAN DREAM 32 (2d ed. 1997). Without a belief or investment in such structure, " $[t]$ he social bonds necessary for discipline ... are weakened." Id. at 98. Most importantly, the strong attachments to family and school long-recognized to divert deviance are weakened. For examples of sources discussing the correlation between strong attachments to the family and decreased deviance, see BRAITHWAITE, supra note 50, at 27-29; TRAVIS HIRSCHI, CaUSES OF DELINQUENCY 85-97 (1969); Travis Hirschi, The Family, in CRIME 121, 128 (James Q. Wilson \& Joan Petersilia eds., 1995). For examples of sources discussing the correlation between strong attachments to school and decreased deviance, see BRAITHWAITE, supra note 50, at 28-29; HIRSCHI, supra, at 120-30; see also sources cited supra notes 5051 and accompanying text (discussing the relationship between juveniles' deviant behavior and detachment from school norms). The effects of formal sanctioning on future delinquency receive mention again later in this Comment, infra note 92. 
fall irretrievably behind ...."66 In addition, school districts often lack alternative education programs for these students. ${ }^{67}$ Only twenty-six states dictate that alternative education placements be made available for those students facing suspension or expulsion. ${ }^{68}$ As a result, physical absence from school grounds may realistically translate into an absence of academic growth and achievement. ${ }^{69}$

\section{JUVENILE JUSTICE INTERVENTION: THE BLURRING OF INSTITUTIONAL BOUNDARIES}

Zero-tolerance methodologies have led to yet another punitive phenomenon. "Today, behaviors that were once punished or sanctioned by the school vice-principal, family members, a neighbor, or a coach are more likely to lead to an adolescent being arrested, referred to juvenile or criminal court, [or] formally adjudicated . . ." Schools have begun to feed youth into the juvenile justice system, rather than deal with the problems solely through internal avenues.

For instance, according to the National Center for Education Statistics' 1996-1997 study on violence in schools, students were arrested for approximately 430,000 incidents occurring on school grounds. ${ }^{71}$ Of this number, only approximately 20,000 involved incidents of a serious, violent nature. ${ }^{72}$ The center's 2003 report exhibits parallel numbers: 656,400 and 34,300 , respectively. ${ }^{73}$ Oftentimes, schools mandate the reporting of misconduct to law enforcement agents. ${ }^{74}$ For

${ }^{66}$ OPPORTUNITIES SUSPENDED, supra note 28 , at vii.

${ }^{67}$ See Polakow-Suransky, supra note 6, at 107 ("Perhaps the most disturbing data trend is the sheer number of expelled students who do not receive an education after being removed from school.").

${ }_{68}$ OPPORTUNITIES SUSPENDED, supra note 28, at 14 and app. III.

${ }^{69}$ The following sources emphasize the importance of alternative education placements and address the potential detriments of leaving youth without such options: Albert Cortez, Alternative Education Programs: Resolution or Exclusion?, 24 INTERCULTURAL Dev. Res. ASs'N NEWSL. (Intercultural Dev. Research Ass'n, San Antonio, Tex.), Nov./Dec. 1997, at 1, available at http://www.idra.org/Newslttr/1997/Nov/ Albert.htm; Bruce I. Wolford \& LaDonna L. Koebel, Reform Education to Reduce Juvenile Delinquency, CRIM. JUST., Winter 1995, at 2, 54-56.

${ }^{76}$ Dohrn, supra note 4, at 158.

71 See HEAVISIDE ET AL., supra note 12, at 5-6, 6 fig.l (providing aggregated data for the different types of crimes reported to the police).

72 $I$.

73 JiLl F. DEVOE ET AL., U.S. DEP'T OF EDUC. \& U.S. DEP'T OF JUSTICE, INDICATORS OF SCHOOL CRIME AND SAFETY: 2003, at $77-78$ tbl.7.2 (2003), available at http:// www.ojp.usdoj.gov/bjs/pub/pdf/iscs03.pdf.

${ }^{74}$ See OPPORTUNITIES SUSPENDED, supra note 28, at app. IV (charting which states mandate reporting certain types of student misconduct to the police). 
example, Missouri state law requires such reporting for the possession of weapons, distribution of drugs, assault, and instances of property damage. ${ }^{75}$ But these mandates and increasing arrest rates come in stark contrast to the more informal sanctions typically practiced prior to the zero-tolerance shift of the 1990s. During the time period leading up to zero-tolerance legislation, even though the crime problem was of similar type-mainly minor infractions and less serious assaults ${ }^{76}$-ninety percent of crimes involving student victimization and seventy-five percent of crimes involving teacher victimization remained unreported to police. ${ }^{77}$ Thus, zero tolerance has effected a drastic change in the educational system's threshold for reporting incidents of school-based crime.

The overlap between the educational and juvenile justice systems has not been unidirectional, however. In fact, the two institutions have intermingled so substantially that a whole host of security measures-once reserved for use by law enforcement officials-have been introduced into the institutions entrusted with the primary mission of developing young minds. Armed guards or actual police officers have been hired to supervise students, surveillance cameras and metal detectors have been installed, and searches of lockers or persons have become more commonplace. ${ }^{78}$ Furthermore, the U.S. Supreme Court has supported schools in these "get-tough" efforts, even though the methods have infringed upon students' civil rights.

\section{A. Extending "Zero Tolerance" to Off-Grounds Enforcement}

The increasingly complicated and intertwined nature of the relationship between schools and juvenile justice has most recently been

${ }^{75}$ MO. ANN. STAT. \$ 160.261 (2) (West 2000).

${ }^{76}$ MARY JOAN MCDERMOTT, CRIMINAL JUSTICE RESEARCh CTR., CRIMINAL VICTIMIZATION IN URBAN SCHOOLS 28 (1979); see also supra notes 34-36, 56, $72-73$ and accompanying text (developing the notion that violent crime occurs relatively infrequently in domestic public schools when evaluated against the much greater number of comparatively minor infractions occurring there).

77 MCDERMOTT, supra note 76 , at 35 .

${ }^{78}$ See SKIBA, supra note 4, at 7-10 (assessing the efficacy of school security measures such as these); Perlstein, supra note 5, at 76 (citing examples of recent attempts to upgrade school security).

${ }^{79}$ See, e.g., Bd. of Educ. of Indep. Sch. Dist. No. 92 v. Earls, 536 U.S. 822, 838 (2002) (upholding a school district's policy to implement drug-testing for all middle and high school students participating in competitive extracurricular activities); New Jersey v. T.L.O., 469 U.S. 325, 343 (1985) (finding reasonable the search of a student's personal belongings in order to enforce an anti-smoking policy). 
compounded by school administrators' attempts to discipline youth for acts committed outside the school's traditional jurisdiction. For example, a Florida school expelled two students for smoking marijuana off campus ${ }^{80}$ while a Pennsylvania school did likewise for a student engaging in drug transactions off campus. ${ }^{81}$ Though the former expulsion was ultimately retracted in response to a court's judgment, ${ }^{82}$ the court based its decision on a lack of evidence, rather than a concern about the substantive value of the policy. ${ }^{83}$ A court upheld the latter one-year expulsion after finding a nexus between the off-campus activity and the school-related behavior. ${ }^{84}$ In another notable situation, a school suspended a student for possessing drug paraphernalia (a pipe) that was found in his car by police during a search off school grounds. ${ }^{85}$ The school's action in that case was later overruled by a court; however, again the court's ruling relied on a procedural issue, rather than a substantive assessment of punishing off-grounds activities. $^{86}$

In addition to collaborating on the actual enforcement of particular off-grounds activities, representatives from both schools and the juvenile justice system have increased their intercommunication about juveniles' behavior more generally. For example, school personnel have partnered up with probation officers and other such professionals to monitor students who have criminal records. ${ }^{87}$ Congress has even twice attempted passage of a bill that would condition

${ }^{80}$ Adam C. Smith, Court Casts Doubt on "Zero-Tolerance" Policy, ST. PETERSBURG Times (Florida), Nov. 14, 1998, at $1 \mathrm{~B}$.

${ }^{81}$ See Giles v. Brookville Area Sch. Dist., 669 A.2d 1079, 1082 (Pa. Commw. Ct. 1995) (upholding a school district's one-year expulsion of a student for engaging in a sale of marijuana which occurred off school grounds).

${ }^{82}$ See Crawley v. Sch. Bd., 721 So. 2d 396, 397 (Fla. Dist. Ct. App. 1998) (per curiam) (reversing the school board's decision to expel two young men for allegedly being present on school property while under the influence of an illegal drug).

${ }^{83} I d$.

${ }^{84}$ See Giles, 669 A.2d at 1082 (arguing that, although the physical exchange of drugs may have taken place off school property, the agreement for the sale of marijuana occurred at school and could reasonably be construed as conduct prohibited by the school's drug policy).

${ }^{85}$ Steve Carney, Focus: School District Loses on Suspension, L.A. TIMES, Sept. 23, 1998, at B2.

${ }^{86} I d$.

${ }^{87}$ See MiChael L. MEDARIS ET AL., U.S. DEP'T OF JUSTICE \& U.S. DEP'T OF EDUC., SHARING INFORMATION: A GUIDE TO THE FAMILY EDUCATIONAL RIGHTS AND PRIVACY ACT ANd Participation IN JUvenile Justice Programs 3-17 (1997) (discussing the information sharing that occurs between schools and other youth-serving agencies as well as the multiagency agreements that facilitate such information sharing). 
certain state funding on the opening of juvenile records to schools. ${ }^{88}$ Though, as of yet, the legislative sponsors have proved unsuccessful in transforming their objective into law, the recurrent requests signify a persistent goal.

At the state level, however, similar efforts have proved successful; state laws already require information exchange between agencies. Texas law, for instance, mandates that juvenile justice officials notify schools when children believed to be enrolled in their institutions have been arrested or detained for any of the following offenses: all felonies, weapons cases, and drug cases; assault; deadly conduct; false imprisonment; indecent exposure; terroristic threats; and organized crime. ${ }^{89}$ Bernadine Dohrn describes the overall trend as a "wholesale relaxation of confidentiality protections for youth," claiming that "[s]chools are routinely notified of a student's non-school-site arrests, probation, or detention." ${ }^{90}$

\section{B. Consequences of Dual Enforcement}

As students are shuffled through the disciplinary procedures of two different institutions, a unique form of "double jeopardy" has evolved: suspension or expulsion on one end and criminal charges on the other. This "double punishment" of sorts creates several problems. With multiple repercussions for each incident, adolescents become further entrenched in processes of formal social control. Consequently, the counterreactions to authority and dissociation from conformist norms discussed earlier ${ }^{91}$ become increasingly likely to occur. An oft-cited longitudinal study conducted at Cambridge University suggests that intervention by the juvenile justice system ironically increases delinquency in many cases. ${ }^{92}$ Moreover, dual punishments

${ }^{88}$ Violent and Repeat Juvenile Offender Accountability and Rehabilitation Act of 1999, S. 254, 106th Cong. $\$ 321$ (1999) (offering such an amendment to 42 U.S.C. $\S 3796$ ee (1996)); Juvenile Justice Reform Act of 1999, H.R. 1501, 106th Cong. $\S 102$ (a) (1999) (same); Juvenile Crime Control Act of 1997, H.R. 3, 105th Cong. $\$ 302$ (1997) (same).

${ }^{89}$ TeX. Code Crim. Proc. ANN. art. 15.27 (Vernon Supp. 2004).

${ }^{90}$ Dohm, supra note 4, at 166.

91 Supra Part I.B.1-2.

${ }^{92}$ See WEST \& FARRINGTON, supra note 65 , at 162 ("It may well be that the processes of conviction help to deter potential delinquents from law-breaking, but our results suggest that, as far as detected and convicted delinquents are concerned, the effects of being convicted are usually the opposite of reformative."). The following sources lend support to this initial thesis: Gordon Bazemore, Delinquent Reform and the Labeling Perspective, 12 CRIM. JUST. \& BEHAV. 131, 160-63 (1985); Frances Palamara et 
erect additional barriers. Excluding a juvenile from school causes her to fall behind academically, and when this disadvantage is compounded by the production of a criminal record, a youth's future choices and chance of success become substantially limited. ${ }^{93}$

Critics of the current setup primarily voice an opposition to the institutional practices and their effects. However, such an intense concentration on the condemnation of zero tolerance may be misplaced since the problem may not be the severity of the policies, but the context in which they are currently operating, one which neglects to include significant provisions for healing and reconnection. In other words, what is missing from the equation? Rehabilitative measures, support, mentorship.

When school sanctioning is handed over to law enforcement in the first instance for the vast majority of minor school infractions, not only do the offender and the victim fail to learn from the incident, and not only is the consequence more likely to be crushing rather than illuminating, but the entire community fails to take hold of the problem as a schoolcommunity matter. ${ }^{94}$

Students are left in a "vacuum," severed from potential support systems and positive adult figureheads. ${ }^{95}$ Avoiding the examination of root causes of deviance, perpetuating erroneous fears about uncontrollable youth, and abandoning adolescents without a forum for reciprocal discourse each exacerbate the "social fissures" already prevalent in American society today. ${ }^{96}$ Ultimately, such negligence creates a

al., The Effect of Police and Mental Health Intervention on Juvenile Deviance: Specifying Contingencies in the Impact of Formal Reaction, 27 J. HEALTH \& SOC. BEHAV. 90, 96-103 (1986). Cf. Malcolm W. Klein, Labeling Theory and Delinquency Policy: An Experimental Test, 13 CRIM. JUST. \& BEHAV. 47, 65-77 (1986) (arguing that, while the type of juvenile justice disposition had little effect on the maintenance of pro-social behavior, initial exposure to the system itself increased the likelihood that youth would identify with a "deviant" or "delinquent" label); Melvin C. Ray \& William R. Downs, An Empirical Test of Labeling Theory Using Longitudinal Data, 23 J. RES. CRIME \& DELINQ. 169, 185 (1986) (discovering a relationship between "baseline formal labels" (derived through agents of social control) and follow-up formal labels, or further interactions with agents of social control).

${ }^{93}$ For example, a future school's enrollment decision or employer's hiring evaluation may hinge on the knowledge of these consequences. See, e.g., Dohrn, supra note 4, at 165 ("Having any delinquency or criminal record has increasing consequences for scholarships, higher education, job eligibility, and escalated sanctions if there is a subsequent police investigation or arrest.").

${ }^{94}$ Id. at 164.

${ }^{95}$ Ron Scherer \& Marjorie Coeyman, Another Shooting, Sharper Questions, CHRISTIAN SCI. MONITOR, May 21, 1999, at 1, 9.

${ }^{96}$ Perlstein, supra note 5, at 77. 
paradox: harsh consequences, the aims of which are to reinforce conformist norms, wind up distancing youth from traditionally accepted systems and pathways.

\section{What Can We Do to Remedy the Zero-Tolerance Frenzy?}

The very system that creates and enforces zero-tolerance programs will not likely undergo a self-reformation. Understandably, policymakers, school administrators, and police officials have been concerned about school violence and misbehavior. These individuals' employment and reputations depend upon how well they tackle the pertinent issues of public concern, and with the recent media hype, "tackling" the issues has translated into drafting policies of zero tolerance-"get[ting] tough." Interestingly, though, even when parents and communities have opposed zero-tolerance endeavors, school boards and administrators have often been unwilling to relent. ${ }^{98}$

Similarly, litigation efforts to reverse the zero-tolerance trend have frequently proved unsuccessful. ${ }^{99}$ In general, courts across the country have held that zero-tolerance sanctions of suspension and expulsion comport with students' due process rights. ${ }^{100}$ Courts even seem willing to uphold fairly extreme school board decisions imposing discipline. ${ }^{10}$

${ }^{97}$ Pedro A. Noguera, Listen First: How Student Perspectives on Violence Can Be Used to Create Safer Schools, in THE PUBlic Assault ON AMERICA'S ChILDREN, supra note 4, at $130,133$.

${ }^{98}$ See SKIBA, supra note 4, at 7 (exposing the "unwillingness on the part of school boards and administrators to back down, regardless of parent or community pressure"). This intractability may reflect the true philosophy of strict, local zero-tolerance policies or provide comfort for decision makers who dread an angry backlash, regardless of the likelihood for such controversy. Either way, however, steadfast blanket enforcement contradicts the federal law's conspicuously incorporated provision allowing for discretion. 20 U.S.C.S. \$ 7151 (b) (1) (Law Co-op. 2003); see also supra text accompanying note 27 (referencing this discretion provision).

99 Most of the challenges to zero-tolerance legislation consist of individual students contesting state legislation or school board decisions.

${ }^{100}$ For examples that exhibit this jurisprudential trend, see London v. Dewitt Public Schools, 194 F.3d 873, 877 (8th Cir. 1999); Smith v. Severn, 129 F.3d 419, 428-29 (7th Cir. 1997); Fuller v. Decatur Public School Board of Education School District 61, 78 F. Supp. 2d 812, 814-16 (C.D. Ill. 2000); Dornes v. Lindsey, 18 F. Supp. 2d 1086, $1089-90$ (C.D. Cal. 1998).

101 See, e.g., James v. Unified Sch. Dist. No. 512, 899 F. Supp. 530, 535-36 (D. Kan. 1995) (upholding the school's zero-tolerance procedure even though the student was not allowed to take final exams or receive final grades); D.B. v. Clarke County Bd. of Educ., 469 S.E.2d 438, 440-41 (Ga. Ct. App. 1996) (ruling that permanent expulsion is a permissible punishment and accords with students' due process rights); Giles v. Brookville Area Sch. Dist., 669 A.2d 1079, 1082 (Pa. Commw. Ct. 1995) (affirming the 
Additionally, even though powerful organizations such as the American Bar Association have voted against zero-tolerance policies, ${ }^{102}$ other influential organizations such as the National School Boards Association, ${ }^{103}$ the National Education Association, ${ }^{104}$ and the American Federation of Teachers ${ }^{105}$ remain in favor of zero-tolerance efforts. In light of this enduring and apparent support and the fact that zerotolerance approaches have been instituted in ninety-four percent of U.S. public schools, ${ }^{106}$ a zero-tolerance mentality and procedural methodology appear to be deeply entrenched. Thus, in order to address the current shortcomings and evident detriment imposed by these inflexible and severe disciplinary practices, worthwhile endeavors may now have to be directed at utilizing the ample discretion conferred on administrators for the implementation of effective alternatives. While many administrators have remained obstinate in ignoring this grant of discretion, extensive efforts to inform the public, school officials, and juvenile justice personnel that discipline alternatives need not translate into diminished accountability, community distrust, or an overhaul of the current guidelines retain great potential for assuring civic leaders that positive reputational and systemic benefits accompany an administrator's choice to pursue a more compassionate, flexible approach.

\section{MOVInG TOWARD REASONABle SOlutions: Restorative Justice}

In dealing with discipline concerns, schools have mainly focused on punitive recourse. Zero-tolerance policies prove a prominent component of this central paradigm, but they are by no means the only apparent aspect of this philosophy. As mentioned in Part II, the

one-year expulsion of a student for a sale of marijuana that did not even occur on school grounds).

${ }^{102}$ Press Release, Am. Bar Ass'n, ABA Votes to Oppose School "Zero Tolerance" Policies (Feb. 19, 2001), http://www.abanet.org/media/feb01/zerotolerance.html; see also RALPH C. MARTIN II, AM. BAR ASS'N, ZERO TOLERANCE REPORT (2001) (outlining the ABA's reasons for its stance).

${ }^{103}$ See NAT'L SCH. BDS. ASS'N, NSBA GUIDELINES: Disciplining STUDENTS FOR SERIOUS OFFENSES (2002), restricted access at http://www.nsba.org/cosa/lawlibrary/cosa _report.cfm?idfield $=1566 \&$ (on file with author) (claiming that zero-tolerance policies can be effective management tools if understood and implemented appropriately).

104 ELLEN M. BoYlan \& JeNNifER Weiser, Educ. LAW CTR. (N.J.), SURVEY OF KeY

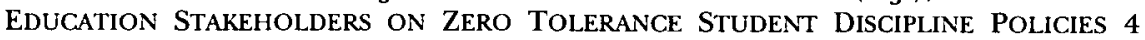
(2002), available at http://www.edlawcenter.org/test/ELCPublic/Publications/PDF/ Survey_ZeroTolerance.pdf.

${ }^{105}$ Id. 
punitive mindset has also manifested itself in the excessive reliance on law enforcement officials or other security devices. ${ }^{107}$ Additionally, while most schools purport to have "violence prevention programs" in place, ${ }^{108}$ only approximately half of these schools achieved substantial participation in these programs for "all or almost all" of their students. ${ }^{109}$ Furthermore, the design of these programs appears questionable. For example, community or parent involvement was included in less than half of the programs, ${ }^{110}$ and rehabilitative efforts for those students already struggling with violent behaviors received little attention."' But as school safety consultants have concluded, safe learning environments ultimately require more than violence prevention programs; mechanisms for conflict resolution must also be available. ${ }^{112}$

Though severe penalties have been purported to "safeguard" both targeted and ancillary youth, ample evidence suggests that youth respond more favorably to positive prevention programs than punitive sanctions. ${ }^{113}$ Furthermore, as previously mentioned, harsh

${ }^{107}$ For example, forty-eight percent of secondary schools report the presence of police or security personnel. KERRY J. GRUBER ET AL., U.S. DEP'T OF EDLC., SCHOOLS and Staffing Survey, 1999-2000: Overview of The Data for Public, Private, Public Charter, and Bureau of Indian affairs Elementary and SEcondary SCHOOLS 22 tbl.1.08 (2002), available at http://nces.ed.gov/pubs2002/2002313.pdf; see also supra note 78 and accompanying text (describing increased security measures in schools).

${ }^{108}$ See HEAVISIDE ET AL., supra note 12, at 23 (acknowledging that seventy-eight percent of public school principals claimed to have some form of violence prevention or reduction program).

${ }^{109}$ Id. at 25 fig. 12,114 tbl.30.

${ }^{110} I d$. at 24,112 tbl.29.

111 Most of the components of violence prevention programs that were reported by schools participating in this survey focused on structural and administrative safeguards (e.g., "training, supervision, or technical assistance in classroom management for teachers") as well as pre-incident, preventative actions (e.g., "social skills training"), rather than post-incident, rehabilitative measures tailored to rectify the damage caused by the particular deviance. Id.

112 See JOHNS \& KEENAN, supra note 46, at 21 (proposing the implementation of peaceful conflict resolution techniques in addition to violence prevention programs (citing David W. JOHNSON \& ROGER T. JOHNSON, Reducing SCHOOL Violence THROUGH CONFLICT RESOLUTION (1995))).

${ }^{113}$ See Barry Krisberg et al., What Works with Juvenile Offenders?, CRIM. JUST., Summer 1995, at 20, 59-60 (emphasizing that rehabilitative measures proved successful with juveniles as did the provision of opportunities for success and self-esteem building); Candace Zierdt, The Little Engine That Arrived at the Wrong Station: How to Get Juvenile Justice Back on the Right Track, 33 U.S.F. L. REV. 401, 430-34 (1999) (promoting community-based rehabilitation of juveniles and utilizing Boston's approach as an example of successful efforts in this regard). 
consequences may breed unintended pejorative consequences of their own. For example, suspended or detained juveniles may experience alienation from supportive social institutions. ${ }^{114}$ But perhaps most important to consider is the punishment mentality's monopoly over behavior modification. After exposing adolescents to the "degradation ceremonies" ${ }^{\prime 15}$ involved in state-sponsored punishment, young offenders internalize messages of rejection and failure; they find themselves searching for havens of acceptance and nurturing. But if little or no effort is made to simultaneously reconnect them to social systems, if positive redirection and reinforcement remain absent, stigmatization may ensue, ${ }^{116}$ propelling juveniles to find solace in antisocial forums.

Once a person is stigmatized with a deviant label, a self-fulfilling prophecy unfolds as others respond to the offender as deviant. She experiences marginality, she is attracted to subcultures which provide social support for deviance, she internalizes a deviant identity, she experiences a sense of injustice at the way she is victimized by agents of social control, her loss of respectability may push her further into an underworld by causing difficulty in earning a living legitimately. ${ }^{117}$

Today's social-control strategies, then, place American students at a greater risk for deviance. With net widening and an expansion of zero tolerance as well as a lack of disciplinary alternatives, students discover that schools are not only quicker to label them "deviant," but that schools are also quicker to disown and discard them. Students internalize this reality, risking further development of an antiestablishment attitude and lifestyle in addition to recurrent encounters with disciplinary authorities.

One way to ameliorate some of this damage caused by the concentration of inflexible and severe repercussions is to implement programs that counter the focus on discipline and reward positive behaviors. For instance, teachers can closely monitor at-risk students, provide mentorship, and create individualized behavior contracts that reward compliant behaviors. Meanwhile, schools can devise programs aimed at reinforcing positive interactions such as skill-building groups

114 See supra notes 50, 64-65 and accompanying text (claiming that delinquent youth typically experience a distancing from social pillars such as the family, community, and school).

${ }_{115}$ BRAITHWAITE, supra note 50, at 101.

${ }_{116}$ See id. (describing the conditions that instigate "stigmatization").

117 Id. at 18; see also ROBERT K. MERTON, SOCIAL THEORY AND SOCIAL STRUCTURE 421-36 (1957) (developing the concept of "the self-fulfilling prophecy"). 
and peer mediation. ${ }^{118}$ But these school-based programs cannot reach those students already excluded from the institutional setting; reasonable solutions must be devised for those children who will still undoubtedly fall within the expansive net of zero-tolerance enforcement, offering them similar "stakes" in maintaining positive behaviors.

\section{A. Restorative Justice Theory}

Restorative justice is a framework for legitimate conflict resolution that incorporates victims, offenders, families of these two groups, and community members or organizations. ${ }^{119}$ By including the opinions of these supplementary groups in determining the consequences of a crime, the restorative justice framework steps beyond a solely offender-centered, retributive approach to address the offenders' relationships to victims and society. The current adversarial structure of criminal justice is based upon the following inquiries: "[W]ho did it[?], [W] hat laws were broken[?], ... [W] hat should be done to the offender[?]"120 A restorative approach, however, asks fundamentally different questions: "[W] hat is the nature of the harm resulting from the crime? .... [W] hat needs to be done to make things right or repair the harm? ... . [W] ho is responsible for this repair?"121

Restorative justice practices, first implemented in the United States during the early $1970 \mathrm{~s},{ }^{122}$ promote the idea that offenders should accept responsibility for the crime committed while concurrently establishing a feeling of resolution or acceptance through agreement. Restorative approaches also emphasize that "crime damages people, communities and relationships" ${ }^{213}$ and that, as a result, victims, communities, and social institutions require answers and

118 See June L. Arnette \& Marjorie C. Walsleben, Combating Fear and Restoring Safety in Schools, JUV. JUST. BULL., Apr. 1998, at 1, 3 (addressing ways to decrease children's fear of violence and promote positive reinforcement for nonbullying activities).

${ }^{119}$ See Gordon Bazemore \& Mark Umbreit, A Comparison of Four Restorative Conferencing Models, JUV. JUST. BULL., Feb. 2001, at 1 (explaining the general theory of "restorative justice").

${ }^{120}$ Gordon Bazemore, A Fork in the Road to Juvenile Court Reform, 564 ANNALS AM. ACAD. POL. \& SOC. SCI. 81, 85 (1999); see also HOWARD ZEHR, CHANGING LeNSES: A NEW FOCUS FOR CRIMINAL JUSTICE 191 (1990) (presenting similar questions).

121 Bazemore, supra note 120 , at 91.

122 Albert W. Dzur \& Alan Wertheimer, Forgiveness and Public Deliberation: The Practice of Restorative Justice, CRIM. JUST. ETHICS, Winter/Spring 2002, at 3.

${ }^{123}$ Marty Price, Personalizing Crime: Mediation Produces Restorative Justice for Victims and Offenders, DISP. RESOL. MAG., Fall 2000, at 8, 9, available at http://www.vorp.com/ articles/justice.html. 
information about the crime in order to "reaffirm a sense of social order." 124 Therefore, while concerned with the consequences of the offense, restorative justice programs do not place their primary focus on punishment; instead, restorative approaches look to a variety of other considerations in measuring outcomes, such as "community empowerment and solidarity, victim interests, and crime prevention."

The general format of restorative justice processes centers around voluntary face-to-face meetings of the parties at which time the victim, community, and/or affected institution can explain the detriment resulting from the offense and suggest means for reparation. ${ }^{126}$ The offenders can utilize the meeting to accept responsibility for their actions and voice their own version of a reasonable resolution. The principal goal of the gathering is to discuss these emotional issues and humanize the context of the offense; reaching a written agreement remains an important, yet secondary, goal. ${ }^{127}$

\section{Proposed Models}

Four main types of restorative justice programs have been implemented within the United States. ${ }^{128}$ Victim-offender mediation, probably the most prevalent form of restorative justice in the United States today, typically involves a trained mediator who facilitates the archetypal face-to-face meeting. This structure generally has been used in conjunction with relatively minor, juvenile crimes, but increasingly is being used in cases of more serious crimes, whether perpetrated by juvenile or adult. ${ }^{129}$

Community reparative boards, another fairly common restorative justice method, seek to divert minor offenders from enduring the fullscale criminal justice process and accumulating criminal records. In

${ }^{124}$ Dzur \& Wertheimer, supra note 122, at 5; see also Mark S. Umbreit, The Meaning of Faimess to Burglary Victims, in CRIMINAL JUSTICE, RESTITUTION, AND RECONCILIATION 47, 50 (Burt Galaway \& Joe Hudson eds., 1990) (finding that seventy-six percent of victims believed obtaining answers to questions about the crime was important and that nearly all victims believed some participation in the criminal justice process was necessary).

${ }^{125}$ Bazemore \& Umbreit, supra note 119 , at 14.

${ }^{126}$ Bazemore, supra note 120 , at 87 tbl.1.

${ }^{127}$ See Bazemore \& Umbreit, supra note 119 , at 2 (“[T] he process should not be primarily focused on reaching a settlement, although most sessions do, in fact, result in a signed restitution agreement.").

${ }^{128}$ See id. at 7-13 (comparing the structures, successes, and criticisms of each of the four typical restorative justice models).

${ }^{129}$ Id. at 2. 
this setup, community members, who have received intensive training, conduct public, face-to-face meetings with offenders to present a range of restitution options. ${ }^{130}$ If the group reaches an agreement, the community board will monitor the offender's compliance with that agreement. $^{131}$

The third restorative structure is circle sentencing, an approach only recently introduced in the United States. ${ }^{192}$ Usually reserved for serious crimes, a convicted criminal awaiting sentencing can apply to participate in the program. ${ }^{133}$ If the application is accepted and all anticipated participants engage in extensive preparation, the vic$\operatorname{tim}(\mathrm{s})$, offender, and family and friends of both will assemble with social service agents, law enforcement officers, interested community residents, and lawyers (depending on the situation) to deliberate on what an appropriate sentencing plan might entail. ${ }^{134}$ Most often, after the sentencing-centered gathering of this "circle" of individuals, some (or all) of the participants continue to monitor the offender's progress and the group's emotional condition through follow-up circle gatherings. ${ }^{135}$

While any of these formats may be utilized in either a school or juvenile justice setting, the fourth and most applicable approach for efficient institutional involvement appears to be family group conferencing. ${ }^{136}$ Family group conferencing involves those individuals

${ }^{130}$ See id. at $3-4$ (outlining the typical procedures employed at reparative board meetings). For an explanation of a specific community reparative board program, see Press Release, City of Philadelphia District Attorney's Office, Adult Volunteers to Serve on Community-Based Youth Aid Panels (Feb. 1, 2002), at http://www.phila.gov/ districtattorney/case/prelease.asp?id=111.

${ }^{131}$ Bazemore \& Umbreit, supra note 119 , at 4.

${ }^{132}$ See id. at 6 (noting that a pilot project was first initiated in Minnesota in 1996). Interestingly, though, circle sentencing as it is practiced in the United States today actually resembles the traditional sanctioning and healing practices of Native Americans. Ada Pecos Melton, Indigenous Justice Systems and Tribal Society, 79 JUDICATURE 126, 126 (1995).

${ }^{133}$ Because of both the numerous procedural steps and participants incorporated into a circle-sentencing regime, this restorative practice "require[s] a substantial investment of citizen time and effort... [and] should not, therefore, be used extensively as a response to first offenders and minor crime." Bazemore \& Umbreit, supra note 119 , at 7 . Circle sentencing involves an application process, in part, for these same reasons.

${ }^{134}$ See id. at 6 (identifying the participants in a circle-sentencing arrangement).

${ }^{135} I$ Id.

${ }^{136}$ See id. ("The family group conferencing process has been implemented in schools, police departments, probation offices, residential programs, community mediation programs, and neighborhood groups. ... Conferencing programs have been implemented within single agencies and developed collaboratively among several 
most affected by the crime committed (most often the victim(s), offender, family members, friends, and administrative representatives). Similar to victim-offender mediation, a trained facilitator (or coordinator) —usually a public official ${ }^{137}$ — convenes a face-to-face meeting of these parties. Family group conferencing is distinctive, however, in that the approach places fairly equal responsibility for devising a reparations plan on all of the parties and support systems present. ${ }^{138}$ This more egalitarian expectation renders the setting ideal for programs involving societal institutions with which the individual will continue to have repeated contact. Though individual accountability is

agencies."). Group conferencing models are actually referred to by a variety of names, depending on the idiosyncrasies of the format. While one conference may allow many third parties to attend, others may restrict the number of participants, or while one facilitator may determine the agenda for a meeting, another program may require facilitators to leave those decisions to the victims and offenders themselves. Since families and communities are particularly integral to the social formation of youth, group conferencing in the school setting will likely be denoted as "family group conferencing" or "community group conferencing."

Family group conferencing models originated in New Zealand and Australia. For examples of articles discussing these origins, see Hennessey Hayes \& Kathleen Daly, Youth Justice Conferencing and Reoffending, 20 JUST. Q. 725, 726-28 (2003); David B. Moore, Shame, Forgiveness, and Juvenile Justice, CRIM. JUST. ETHICS, Winter/Spring 1993, at 3; Kenneth Polk, Family Conferencing: Theoretical and Evaluative Concerns, in FaMILY CONFERENCING AND JUVENILE JUSTICE: THE WAY FORWARD OR MISPLACED OPTIMISM? 123, 123-25 (Christine Alder \& Joy Wundersitz eds., 1994). New Zealand's program received national sanction in 1989 through its parliament's legislative adoption of family group conferencing. Children, Young Persons, and Their Families Act, 1989, $\$ \$ 20-38$ (N.Z.). South Australia included conferencing as part of a statutory scheme established in the Young Offenders Act of 1993. Young Offenders Act, 1993, $\S \S 7,9$ 12 (S. Austl.).

${ }^{137}$ See Mark Umbreit \& Howard Zehr, Restorative Family Group Conferences: Differing Models and Guidelines for Practice, FED. Probation, Sept. 1996, at 24, 25 (stating that, unlike other restorative justice paradigms, family group conferencing utilizes public officials, rather than trained community volunteers, as facilitators). While law enforcement officials usually play a role of some kind in family group conferencing, some programs prefer to deemphasize the primacy of law enforcement in the process. For example, the prevalent conferencing modeis in both Australia and New Zealand "ha[ve] at least two professionals present (a police officer and a conference coordinator)." Hennessey \& Daly, supra note 136 , at 726 n.1. Thus, the police officer plays a minimized role, serving as an "authoritative legal presence" and reciting the potential effects of future criminal activity, while the conference coordinator is expected to direct the course of the discussion. Id. at 727. This particular structuring suggests that the role of coordinator could be assumed by a variety of individuals in the public service arena. For instance, school administrators, teachers, or social service agents could retain organizational authority over the program, though in order to avoid cases of potential "double jeopardy" as described in this Comment, juvenile justice officials would also need to be involved at some point.

138 See Bazemore \& Umbreit, supra note 119, at 5 (noting that participants in family group conferencing sessions maintain a "collective responsibility"). 
encouraged, offenders are "reconnect[ed]" to and supported by "key community support systems," thereby reinforcing their stake in conformist behaviors and allowing for the reclamation of their social location. $^{139}$

To illustrate the implementation of this final proposed model in a school setting, an example may be beneficial. Perhaps a student engages in an altercation with her teacher, subsequently pushing the teacher and breaking a coffee mug that the teacher had been holding. A zero-tolerance policy might direct administrators to invoke an immediate term of out-of-school suspension. In addition, a police officer may be alerted about the incident, and an arrest could occur. However, if the school retained family group conferencing as an option, it could ultimately handle the situation internally-regardless of the immediate precautions taken. Participants at the conference could include the student, her parent(s) and other close relatives, the teacher (victim), school administrators and other teachers who deal with the student, and any implicated law enforcement officials. These parties would each have a chance to describe the offense and verbalize their feelings about its impact. The subsequent discussion would center around appropriate consequences aimed at repairing the harms mentioned. The group may decide that the student owes restitution for the coffee mug and any medical expenses incurred. It may also determine that she owes the teacher, and/or the school more generally, an apology letter and a certain number of community service hours. By agreeing to this resolution, the student could remain in school, begin rebuilding a positive relationship with her teacher, and become further invested in the school's culture as she performs the requisite service. This scenario actually parallels the situations referred to in a number of successful, real-world, family group conferencing structures. ${ }^{140}$

${ }^{139} I d$. at 6.

${ }^{140}$ See, e.g., id. at 5 (citing an example of an actual family group conference regarding a teacher who had been assaulted); Mark Umbreit \& Claudia Fercello, Practicing Restorative Justice: Family Group Conferencing and Juvenile Crime in the Suburban Metro Area, CURA REP., June 2000, at 15, 16 (studying the family group conferencing cases of twelve sites in Minnesota and noting that forty percent of the cases involved crimes against persons, "principally minor assaults, such as school fights"), available at http://www.cura.umn.edu/reporter/00-Jun/article3.pdf; see also Paul McCold, Cmty. Serv. Found. \& John Stahr, Bethlehem Police Dep't, Bethlehem Police Family Group Conferencing Project (1996), at http://www.iirp.org/library/bethlehem.html (introducing the Bethlehem, Pennsylvania, program with an anecdote about family group conferencing's success in resolving the archetypal school fight). 


\section{State-Specific Examples}

Traditionalists have tended to criticize proponents of restorative justice for their seemingly ungrounded idealism, insular morality, and lack of emphasis on practical concerns. ${ }^{141}$ Of course, the somewhat subjective nature of these criticisms limits restorative justice proponents' ability to defend the practice. Nevertheless, the consistent growth of the restorative justice field, in addition to the favorable qualitative and empirical data retrieved following restorative endeavors, ${ }^{142}$ challenge the credibility of the perception that restorative justice is a concept better left to the realm of theoretical debate and omitted from real-world, criminal justice reform efforts. And to refute the perception on a level more specific to this Comment's topic, the remainder of this subsection provides examples of successful, schoolbased, restorative justice programs.

Restorative school environments exist in geographic "pockets" across the country. ${ }^{143}$ To name but a few examples, communities in Illinois, ${ }^{144}$ Virginia, ${ }^{145}$ and Hawaii ${ }^{146}$ have incorporated restorative practices into their school strategies for conflict resolution.

At present, [however,] the following three geographical locations represent the collective ideological and pragmatic center of the schoolbased restorative justice movement in the United States: the statewide

${ }^{141}$ For instance, some commentators imply that restorative justice stems from one lobby's esoteric and quixotic view of morality. See Dzur \& Wertheimer, supra note 122 , at 15 (suggesting that, because proponents of restorative justice tend to work closely with criminal offenders, they suffer from a "myopia" of sorts); Margaret R. Holmgren, Punishment as Restitution: The Rights of the Community, CRIM. JUST. ETHICS, Winter/ Spring 1983, at 36, 37 (arguing that using a criminal as the "means to promote social goals" is not an adequate justification in and of itself).

${ }^{142}$ See infra Part III.B.2 and text accompanying notes 166-67 (describing the higher levels of victim satisfaction and offender compliance that have resulted from restorative justice methods).

143 David R. Karp \& Beau Bresiin, Restorative Justice in School Communities, 33 YOUTH \& SOC'Y 249, 254 (2001).

${ }^{144}$ See, e.g., Steans Family Found,, Lawndale Restorative Justice Collaborative, at http://www.steansfamilyfoundation.org/action/barj/html (last visited Jan. 14, 2004) (describing a restorative justice program in North Lawndale, Illinois, that represents schools, churches, the court system, the police department, and the community).

${ }^{145}$ See Paul McCold, Virginia Conference Project: A Four-Site Evaluation (1999), at http://www.iirp.org/library/vaproject.html (detailing the activities of four restorative justice programs in Virginia that focus on "juveniles in justice and educational settings").

${ }^{146}$ See Lorenn Walker, Conferencing-A New Approach for Juvenile Justice in Honolulu, Fed. Probation, June 2002, at 38, 39-42 (recounting an experimental juvenile diversion project that utilized conferencing for various school offenses). 
school system in Minnesota, ... schools in the Denver metropolitan area, and a small band of... "alternative" facilities located in southeastern Pennsylvania. ${ }^{147}$

The state of Minnesota adopted a restorative plan to offer educational institutions an additional resource for handling school-related discipline internally. ${ }^{148}$ Teachers, administrators, and members of the community were trained in restorative techniques and welcomed to participate in conferences regarding specific offenses. ${ }^{149}$ Statistics gathered as a result of Minnesota's progressive initiative seem promising. "[A]lmost half the school districts in Minnesota are making some use of restorative practices," ${ }^{150}$ and evaluations have reported dramatic

${ }^{147}$ Karp \& Breslin, supra note 143, at 254. Although David Karp and Beau Breslin also reported that the Denver program involved fifteen schools and that Pennsylvania's Buxmont Academy included six schools, id., currently, group conferences are being conducted in approximately twenty secondary schools located in over ten different school districts surrounding the Denver metropolitan area, Telephone Interview with Kate Kendrick, Restorative Justice Coordinator, School Mediation Center (Sept. 11, 2003); Telephone Interview with Anne Rogers, Executive Director, Forum on Restorative Community Justice (Sept. 11, 2003), and a total of eight schools have been incorporated into the Buxmont Academy initiative, Cmty. Serv. Found. \& Buxmont Acad., History of Organizations, at http://www.csfbuxmont.org/Pages/history.html (last visited Jan. 23, 2004).

${ }^{148}$ See Karp \& Breslin, supra note 143, at 256 (outlining the establishment of Minnesota's five-year restorative justice plan). Minnesota state law has even recognized restorative justice. See, e.g., MINN. STAT. § 611 A.775 (2003) (affording "communitybased organization [s]" the authority to establish "restorative justice program [s]" and describing the components of such programs); State v. Pearson, 637 N.W.2d 845, 849 (Minn. 2002) ("[A]ny limitation on the agreement to send a case to a restorative justice program, if allowable at all, must be made up front, before the laborious process of reconciliation and resolution takes place.").

${ }^{149}$ Karp \& Breslin, supra note 143 , at 256 . It is appropriate here to note the distinction between an overall restorative environment, or "restorative milieu," as it has been called, Paul MCCOLd, INT'L INST. FOR Restorative Practices, Evaluation of

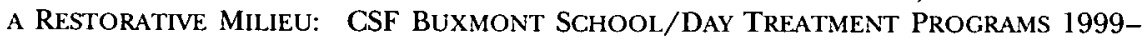
2001, EVALUATION OUTCOME TECHNICAL REPORT (2002), available at http://fp.enter. net/restorativepractices/erm.pdf, and an offense-specific restorative intervention such as a conference. In relation to school settings, the former tends to involve general classroom management techniques such as daily circle times, peer mediation, and antiviolence or anti-bullying curricula. See NANCY RIESTENBERG, MINN. DEP'T OF CHILDREN, FAMILIES, \& LEARNING, IN-SCHOOL BEHAVIOR INTERVENTION GRANTS FINAL REPORT 1999-2001, at 1 (2001) (offering examples of restorative measures practiced as part of daily classroom management), available at http://education.state.mn.us/ stellent/groups/public/documents/translatedcontent/pub_041622.pdf. In contrast, offense-specific efforts are implemented to deal with the consequences from one particular incident of inappropriate behavior. Minnesota's restorative justice plan has integrated both types of restorative initiatives into the school culture.

${ }^{150}$ Karp \& Breslin, supra note 143 , at 256. 
reductions in delinquency at both the elementary- and secondaryschool levels. ${ }^{151}$

Denver's restorative justice project, pioneered by the School Mediation Center (SMC), ${ }^{152}$ a nonprofit organization located in Boulder, Colorado, has also aimed its efforts at elementary, middle, and high schools. ${ }^{153}$ Denver area schools have used a variety of informal and formal restorative justice methods, ranging from impromptu classroom meetings during which other students can give feedback on a particular student's misbehavior to victim impact panels that allow victims of similar offenses to tell their stories to an attendant perpetrator of that offense. ${ }^{154}$ These schools have also experimented with a multitude of organizational arrangements. For example, Broomfield schools contract with personnel from the Department of Health and Human Services as well as SMC to provide conference facilitation, Boulder schools have experimented with student facilitation, and participating Loveland schools have developed an internally administered conferencing program. ${ }^{155}$

Despite the availability of these diverse approaches, the Denver programs have preferred fairly structured conferences for offenses such as drug possession, vandalism, theft, assault, and harassment. ${ }^{1.5}$ After the victim, offender, administrators, and any willing family and

${ }^{151}$ See id. at 257 (identifying significant reductions in disciplinary action for particular elementary and high schools); see also RIESTENBERG, supra note 149, at 10-11 (emphasizing that, after the implementation of restorative measures, elementary schools experienced an overall decrease in discipline referrals and the high school students improved their academic performance). More specifically, one Minnesota elementary school's number of in-school suspensions dropped from sixty-one per month in 2001-2002 to thirteen per month at the beginning of the 2002-2003 term. Nancy Riestenberg, Aides, Administrators and All the Teachers You Can Get, VOMA CONNECTIONS, Winter 2003, at 7.

${ }^{152}$ This nonprofit was formerly known as the Colorado School Mediation Project.

153 See Karp \& Breslin, supra note 143, at 259-60 (describing the general characteristics of Denver's initiative). Like Minnesota, the Colorado state government has exhibited legal support for restorative justice efforts. Most notably, the Colorado state legislature incorporated a legislative declaration at the beginning of title 19 , article 2 , denoting restorative justice as a premiere and all-encompassing philosophy for the treatment of youth in the juvenile justice system. COLO. REV. STAT. \$ 19-2-102 (2002).

${ }^{154}$ Karp \& Breslin, supra note 143 , at 260 . The more informal techniques practiced by these schools would likely be considered part of a "restorative milieu."

${ }^{155}$ Telephone Interview with Kate Kendrick, supra note 147; see also Alice Ierley \& Carin Ivker, Restoring School Communities: A Report on the Colorado Restorative Justice in Schools Program, VOMA CONNECTIONS, Winter 2003, (Insert), at 1, 2 (noting the Department of Health and Human Services' "long-term commitment" to helping Broomfield schools maintain a restorative environment).

${ }^{156}$ Ierley \& Ivker, supra note 155, at 2; Karp \& Breslin, supra note 143, at 260. 
community participants each share their perspectives, an agreement is drafted, containing commitments for the parties involved. A study of SMC's spring 2002 group conferences notes not only that one hundred percent of the groups reached an agreement, but also that the terms of those agreements most often included the following: a "commitment to change behavior," apologies, restitution, and community service. ${ }^{157}$

Though a solely restorative approach may be idyllic, the Denver schools ultimately remain flexible in their disciplinary responses, employing a combination of both restorative justice and traditional, punitive techniques. ${ }^{158}$ For instance, if a student has committed a more serious offense, a school in this program is likely to involve law enforcement officials initially and then integrate restorative justice methods into the action plan upon that student's reentry. ${ }^{159}$

In 1984, the Community Service Foundation, a nonprofit organization situated in Pennsylvania, began opening alternative schools that utilize restorative practices. ${ }^{160}$ As of now, the organization has instituted a total of eight schools, collectively known as Buxmont Academy. ${ }^{161}$ Because the Pennsylvania examples apply to alternative school settings, their styles and issues are distinct from the typical school atmosphere. For example, many of the students already retain probation officers or other case managers who must be notified and integrated into the restorative forums. However, even these programs, with their intensified exposure to juvenile justice representatives,

${ }^{157}$ Ierley \& Ivker, supra note 155 , at 2.

${ }^{158}$ See Karp \& Breslin, supra note 143, at 261 ("[SMC] ... recommends a loose combination of restorative justice and traditional punitive responses when dealing with the more severe criminal offenses.").

${ }^{159}$ See id. (explaining how these Denver schools deal with serious juvenile offenses). Reentry conferencing, while at times not as proactive or potentially harmreducing as conferencing accomplished prior to the determination of serious consequences, still allows for reintegrative shaming and the exercise of restorative philosophy. See infra text accompanying notes 175-82 for a description of the "reintegrative shaming" concept. Moreover, particularly in light of the currently entrenched zerotolerance regime, reentry conferencing may prove a practical "next step" in this subset of criminal justice reform. Reentry conferencing poses a less dramatic change to the structures of the school and juvenile justice systems. Consequently, to the school administrators and law enforcement officials most invested in the zero-tolerance model, reentry conferencing may appear a less "risky" measure for experimenting with reform efforts, thus providing a possible catalyst for further change and the persuasion of more resistant entities.

${ }^{160}$ Cmty. Serv. Found. \& Buxmont Acad., supra note 147.

161

Id. 
facilitate a similar type of conferencing through which community members can voice concerns and offer solutions. ${ }^{16}$

\section{B. The Benefits of Embracing, Rather than Jeopardizing, Our Youth}

\section{Administrative, Social, and Individual Advantages}

Restorative justice programs extend resources to those youth who have been physically alienated from school settings and/or placed in the juvenile justice system, allowing educational and juvenile justice institutions to deal with the ambiguities and particularities of an individual's case. Through the active participation required by the restorative justice methods, members of each side in a dispute retain a "stake" in the outcome and gain empowerment through the opportunity to voice opinions. ${ }^{163}$ In addition, personal participation challenges and deconstructs the "demonization" imagery with which the public is inundated. ${ }^{164}$

Moreover, government agencies may actually save monetary resources through the implementation of restorative methods. Restorative justice practices permit both individuals and institutions to skip the adversarial contest altogether, thus avoiding potentially expensive litigation costs. While some critics contend that restorative settlements will ultimately require adversarial settings for enforcement and legitimacy, ${ }^{165}$ this objection presupposes that the parties will not follow

162

See Karp \& Breslin, supra note 143, at 264-66 (describing the unique population of an alternative school and the restorative measures used to meet such distinct needs); see also McCold \& Stahr, supra note 140 (presenting the structure of Bethlehem, Pennsylvania's, Police Family Group Conferencing Project, a partnership between the Community Service Foundation and the Bethlehem Police Department that serves the area surrounding one Buxmont school; explaining its interaction with juvenile offenders; and purporting an overwhelming success rate).

153 "Active participation" has been heralded as an essential component for the positive redirection of American youth. See, e.g., Dohrn, supra note 4, at 181 ("Addressing the needs of both public safety and positive youth development requires an active and participating public.").

${ }^{164}$ See id. (discussing the impact of persistent negative stereotypes surrounding today's youth); supra Part I.B.1-2 (same).

${ }^{165}$ See, e.g., Kevin I. Minor \& J. T. Morrison, A Theoretical Study and Critique of Restorative justice, in RESTORATIVE JUSTICE: INTERNATIONAL PERSPECTIVES 117, 128 (Burt Galaway \& Joe Hudson eds., 1996) (noting the following paradox for restorative justice theory: restorative justice practices presume wide-scale community participation, yet this involvement cannot occur without some tie to state authority, the exact mechanism that distanced community voices in the first instance). While it remains less clear whether communities would motivate for benevolent and humanitarian reasons in 
through with their obligations unless prodded by court-imposed sanctions. In contrast to this view, a study analyzing the victim-offender mediation practices in North America found that over ninety percent of restitution agreements were completed within one year. ${ }^{166}$ These numbers, in fact, contrasted with the rate of payment for courtordered restitution. Offenders in that scenario complied with restitution agreements at a rate of only twenty to thirty percent. ${ }^{167}$ Furthermore, even if some contracts will be referred to adversarial courts for enforcement of their provisions, contract enforcement is a relatively straightforward legal claim and could actually save administrative resources when compared to the typical juvenile adjudication because the terms will have been worked out-in a less costly arena-ahead of time, leaving few contentious issues or defenses.

Of unique importance, however, is the capability of restorative justice practices to integrate community involvement. Our current fears about unabated youth violence, our own personal ties to numerous juveniles, and the dependence we all place on youth as the "prospective hope" for our future ${ }^{168}$ prove each of us a "stakeholder" in the resolutions of juvenile offenses. "A community problem necessitates community-wide solutions." 169

Zero-tolerance measures and a general retributive philosophy, though, have frequently left interested parties with little influence over the way such justice is determined. Critics have blamed this lack

contrast to those inclinations spurred by state legitimacy, current community disempowerment has proven a more accurate and pressing critique.

Ironically, those communities most in need of holistic restorative justice programs that encourage residents to become involved in the disposition process are often precisely those communities that are the most dysfunctional. Also, residents of such communities may have only limited interest in and/or capacity for involvement, in part because they have never had the opportunity to develop meaningful partnerships with the juvenile justice system.

Bazemore \& Umbreit, supra note 119, at 16.

These challenges to restorative justice theory parallel the arguments given in opposition to alternative dispute resolution generally. See, e.g., Deborah R. Willig, Arbitration of Discrimination Grievances: Arbitral and Judicial Competence Compared, 1986 PROC. THIRTY-NinTH ANN. MEETING; NAT'L ACAD. ARBITRATORS 101, 104-05 (listing seven major objections to arbitration, including the lack of legal finality).

${ }_{166}$ Price, supra note 123, at 9.

${ }^{167}$ Id

168 Dohrn, supra note 4, at 181.

169 NAT'L ASS'N OF STATE BDS. OF EDUC., SCHOOLS WITHOUT FEAR: THE REPORT OF THE NASBE STUDY GROUP ON VIOLENCE AND ITS IMPACT ON SCHOOLS AND LEARNING 4 (1994), available at http://www.nasbe.org/Educational_Issues/Reports/ Schools\%20without\%20Fear.pdf. 
of community empowerment for much of the net widening problem, ${ }^{170}$ sensational media coverage, ${ }^{171}$ and increasing social disorganization. ${ }^{172}$ Community involvement, on the other hand, offers groups and institutions critical opportunities to define their own versions of justice and resolidify bonds with distanced members.

Restorative justice programs enable schools and communities to address the specific needs of their neighborhoods and particular crime problems. They can develop reparations agreements which include a variety of mechanisms for tangibly improving school/ community life. For example, reparations may include community service projects valued by the group, work opportunities provided by the community or school that facilitate the offender's payment of restitution to victims, counseling or treatment programs that address personal emotional issues as well as victim empathy and accountability, and community education endeavors. ${ }^{173}$ Additionally, the offender's reparations will often make the individual a more productive member of society through the development of enhanced academic, practical, and interpersonal skills.

The psychic benefits for the involved parties are equally important. In humanizing the crime, victims will feel more empowered and relieved while offenders will simultaneously be more apt to experience empathy and remorse. The combination of these emotional processes

${ }^{170}$ The following sources address the increasing number of youth brought under the guidance of the juvenile justice system when juvenile justice authorities refuse to share their discretion with communities: Thomas G. Blomberg, Diversion's Disparate Results and Unresolved Questions: An Integrative Evaluation Perspective, 20 J. RES. CRIME \& DELINQ. 24, 29 (1983); Polk, supra note 136, at 126-29.

${ }^{171}$ Without the integration of community voices, community members and larger social institutions are left isolated from the problems of their young members as well as vulnerable to the overdramatized and selective reporting of the media. See Arnette \& Walsleben, supra note 118, at 1-2 (suggesting that the media has "helped engender widespread fear that violent acts are taking an unacceptable toll on ... education"). Not every school will experience a Columbine-level situation. Consequentiy, intracommunity communication regarding the realistic threats to education is, in and of itself, one of the most valuable forms of education.

${ }^{172}$ Social disorganization results from the disintegration not only of the bonds between community members, but also of the "vertical linkages between communities and larger political, social, and economic institutions." Jack R. Greene, Communities and Crime: Reflections on Strategies for Crime Control, in WHAT CAN THE FEDERAL GOVERNMENT DO TO DECREASE CRIME AND REVITALIZE COMMUNITIES? 45, 46 (Nat'l Inst. of Justice, U.S. Dep't of Justice ed., 1998).

${ }^{173}$ See, e.g., Frieder Dünkel \& Dieter Rössner, Law and Practice of Victim/Offender Agreements, in Mediation and Criminal Justice: Victims, OfFENdERS AND CoMMUNITY 152, 161-69 (Martin Wright \& Burt Galaway eds., 1989) (providing examples of various requirements included in victim-offender agreements). 
allows for the greater likelihood that a perpetrator can restore her location in the school and community and will genuinely desire to do so. These processes can also "calm fears [and] challenge stereotypes," ${ }^{174}$ which may be particularly important for schools and neighborhoods struggling with negative media stigmas.

Lastly, restorative justice processes provide an optimal environment for the practice of "reintegrative shaming.,"175

Reintegrative shaming is shaming which is followed by efforts to reintegrate the offender back into the community of law-abiding or respectable citizens through words or gestures of forgiveness or ceremonies to decertify the offender as deviant. Shaming and reintegration do not occur simultaneously but sequentially, with reintegration occurring before deviance becomes a master status. It is shaming which labels the act as evil while striving to preserve the identity of the offender as essentially good.

Unlike the stigmatization likely to occur in situations of purely punitive attention, ${ }^{177}$ shaming can reaffirm an offender's morality and offer the perpetrator a chance to witness others' investment in her well-being. ${ }^{178}$ In addition, the positive effects of reintegrative shaming spill over to ancillary individuals, influencing other students/youth who witness the institutional and societal messages of wrongdoing and condemnation $^{179}$ (in contrast to an exclusionary system in which other students may only witness the initial removal). Moreover, educational agencies themselves can benefit on a level separate from the benefits procured for their particular students; “[w] hen ... collectivities are put on notice as to their responsibility to exercise informal control over their members ... the moralizing impact of shaming is multiplied." 180 Reintegrative shaming allows schools to provide a firm but

${ }^{174}$ Dzur \& Wertheimer, supra note 122 , at 7.

${ }^{175}$ The concept of "reintegrative shaming" was first introduced in John Braithwaite's work, Crime, Shame and Reintegration. BRAITHWAITE, supra note 50, at 55.

${ }^{176}$ Id. at 100-01 (emphasis omitted).

${ }^{177}$ Supra Parts I.B, II.B.

${ }^{178}$ See BRAITHWAITE, supra note 50, at $72-73$ (“[S] haming can be a reaffirmation of the morality of the offender by expressing personal disappointment that the offender should do something so out of character, and if the shaming is reintegrative, by expressing personal satisfaction in seeing the character of the offender restored.").

${ }^{179}$ See id. at 77 (explaining that such community-wide shaming is necessary to adequately socialize children with regard to generally accepted perceptions about crime, since the average household-the primary source of early socialization-does not experience most crimes).

${ }^{180}$ Id. at 83 . 
nurturing environment ${ }^{181}$ while reinstituting an adolescent's investment in conformist norms, minimizing social distance, and decreasing the need to resort to formal and costly accountability mechanisms. ${ }^{182}$

\section{Success Rates}

Recent studies have established that both victims and offenders appear more satisfied with the results generated from restorative justice discussions than those generated from traditional methods of dispute resolution. ${ }^{183}$ Victims who met with offenders in some form of restorative program (victim-offender mediation, family group conferencing, etc.) were more likely to be satisfied with both the outcome and the system as a whole than were similarly situated victims who entered into the court process. ${ }^{184}$ Offenders also noted that they, too, appreciated the opportunity to speak with the other party and felt better after doing so. ${ }^{185}$ In addition, offenders usually had lower

${ }^{181}$ See James Q. Wilson \& Richard J. HerRnstein, CRime and Human Nature 283 (1985) (finding that a "warm but restrictive" environment in which rules are applied with consistency and firmness proves most successful in terms of minimizing delinquency).

${ }^{182}$ See BRAITHWArTE, supra note 50, at 149 ("The point is that formal accountability mechanisms are inferior substitutes for trust that is nurtured by the shame, conscience and mutual obligation of a communitarian culture.").

${ }^{183}$ See Paul McCold \& Ted Wachtel, Restorative Justice Theory Validation, in RESTORATIVE JUSTICE: THEORETICAL FOUNDATIONS 110, 125-36 (Elmar G.M. Weitekamp \& Hans Jürgen Kerner eds., 2002) (analyzing victim and offender perception data from numerous restorative justice programs); see also MARK S. UMBREIT, VICTIM MEETS OFFENDER: THE IMPACT OF RESTORATIVE JUSTICE AND MEDIATION 75-97, 101-04 (1994) (presenting survey data to highlight the increased likelihood that both victims and offenders would experience fairness and satisfaction in mediation as opposed to alternative resolution forums); Robert B. Coates \& John Gehm, An Empirical Assessment, in MEdiATION AND CRIMINAL JUSTICE: VICTIMS, OFFENDERS AND COMMUNITY, supra note 173 , at 251, 253-56 (assessing victims' and offenders' reactions to, and satisfaction with, victim-offender mediation programs).

184 McCold \& Wachtel, supra note 183, at 135; see also UMBREIT, supra note 183 , at 79,80 fig. 16 (finding that ninety percent of victims surveyed acknowledged their satisfaction with their victim-offender mediation outcome).

${ }^{185}$ For example, in a study that tracked victim-offender mediation, Mark Umbreit discerned that two-thirds of the offenders studied felt "cathartic relief" in telling their story. UMBREIT, supra note 183, at 101. "Even more often than expressing their feelings, young offenders talked about welcoming the chance to tell the victim their side of the story." Id. Robert Coates and John Gehm report similar results:

Offenders were most satisfied with: (a) meeting the victim and discovering the victim was willing to listen to him or her; (b) staying out of jail and in some instances not getting a record; (c) the opportunity to work out a realistic schedule for paying back the victim to "make things right."

Coates \& Gehm, supra note 183, at 254. 
recidivism rates after attempting restorative solutions as opposed to following more formalized procedures. ${ }^{186}$ A study by Paul McCold and Ted Wachtel concluded that, overall, more than eighty percent of victims and offenders were satisfied with restorative justice methods as compared to the fifty-six percent of victims and seventy-three percent of offenders that claimed satisfaction with the existing system. ${ }^{187}$ These empirics represent a system that appears much better able to meet the needs of both juvenile offenders and their victims.

Within the rubric of restorative justice programs, family group conferencing exhibits the greatest success. In fact, ninety-one percent of victims and ninety-five percent of offenders professed satisfaction with this restorative format. ${ }^{188}$ In addition to this high level of participant satisfaction, family group conferencing generates a high degree of offender compliance. ${ }^{189}$ The success of this approach in particular

186

See UMBREIT, supra note 183 , at 115 \& fig.27 (observing that offenders in restorative justice programs reoffended at a rate of eighteen percent as opposed to those offenders who chose traditional dispute resolution and reoffended at a rate of twentyseven percent); John Braithwaite, Restorative Justice: Assessing Optimistic and Pessimistic Accounts, in 25 CRIME AND JUSTICE: A REVIEW OF RESEARCH 1, 27 (Michael Tonry ed., 1999) (citing various studies "all report[ing] a decline in recidivism among mediation cases"); Edmund F. McGarrell, Restorative Justice Conferences as an Early Response to Young Offenders, JUV. JUST. Bull., Aug. 2001, at 1, 8 (finding that restorative conferencing resulted in a twenty-nine percent reduction in rearrest rates for juveniles during the first twelve months following the conferencing).

${ }^{187}$ McCold \& Wachtel, supra note 183, at 135; see also UMBREIT, supra note 183 , at 75 ("Nearly all victims and offenders indicated that their mediation was fair.").

${ }^{188}$ McCold \& Wachtel, supra note 183, at 135; see also CLAUDIA FERCELLO \& MARK UMbreit, CTR. FOR Restorative Justice \& MEdiation, Client Evaluation of FAMILY GROUP CONFERENCING IN 12 SITES IN 1ST JUDICIAL DisTRICT OF MINNESOTA 9 tbl.7 (1998) (calculating that $93.3 \%$ of victims and $94.2 \%$ of offenders concluded the family group conferencing process satisfied with their experience), available at http:// sss.che.umn.edu/rjp/Resources/Documents/ferumb98.pdf; PAUL MCCOLD \& BENjamin Wachtel, Cimty. Serv. Found., Restorative Policing Experiment: The Bethlehem Pennsylvania Police Family Group Conferencing Project 5 (1998) (indicating that victims, offenders, and parents involved in conferences were more likely to feel that their opinions mattered and that the outcome was tailored to specific needs), available at http://fp.enter.net/restorativepractices/BPD.pdf. But see Mark S. Umbreit \& Susan L. Stacey, Family Group Conferencing Comes to the U.S.: A Comparison with Victim-Offender Mediation, JUV. \& FAMILY CoURT J., Spring 1996, at 29, 34-36 (describing four potential problems with the process for both victims and offenders, including the possibility that parties would be more intimidated because of authority figures' significant involvement and the danger that new alternative justice programs may cause net widening of their own); Umbreit \& Zehr, supra note 137, at 27 (citing potentially dangerous situations in which victims would not be protected under the family group conferencing model).

${ }^{189}$ See Nat'l Inst. Justice, Family Group Conferencing, at http://www.ojp.usdoj.gov/ $\mathrm{nij} /$ rest-just/ (last visited Jan. 30, 2004) (asserting that "[p] reliminary program evaluations in the United States ... indicate ... high rates of compliance by offenders with 
depends largely on the communication and partnership between the juvenile justice system and community institutions. In this sense, the increasing overlap between schools and the juvenile justice system may actually benefit youthful offenders, facilitating reconstruction of the systems in a more nonthreatening, receptive fashion.

\section{CONCLUSION}

Clearly, the current preference of school administrators is to push the punitive, to provide each student with one chance and tenaciously hold her accountable for any failings. In doing so, the administrators themselves deviate from the expected norm. They trivialize the psychological underpinnings of juvenile socialization and ignore the rational arguments which led to the creation of a separate juvenile justice system in the first place.

"Historically ... the juvenile justice system has ... focused on the care and rehabilitation of the child rather than on punishment and incapacitation." 900 Youth, while still facing accusations of criminal behavior, were "offered assistance, treatment, and guidance." American educational facilities must reclaim the remnants of these longstanding philosophies. While taking adequate precautions and remaining firm in their discipline, schools can additionally address individual needs and extend support to struggling students. Such support is crucial to the sustenance of social cohesion.

Unlike blanket zero-tolerance policies, restorative justice practices provide schools with the tools and flexibility to address, confront, and resolve the inherent ambiguities in particularized conflicts. They offer students the chance to voice their opinions and accept responsibility for their actions while simultaneously allowing administrators to retain authority in directing consequences. Furthermore, restorative justice programs incorporate community involvement. Of vital importance at a time when public pressure in the educational realm remains evident and influential, the active participation of community

the agreements reached during conferences"); see, e.g., Ierley \& Ivker, supra note 155, at 2 (noting that, of a group of twenty offenders participating in conferencing, nineteen fully completed the terms of the resultant agreements); McGarrell, supra note 186 , at 8 ("Youth participating in restorative justice conferences demonstrated a significantly higher completion rate $(82.6$ percent) than youth in the control group, who were assigned to other diversion programs (57.5 percent).").

190 Eric K. Klein, Dennis the Menace or Billy the Kid: An Analysis of the Role of Transfer to Criminal Court in Juvenile Justice, 35 AM. CRIM. L. REV. 371, 373 (1998).

${ }^{191}$ Id. at 376. 
members allows the broader society to disintegrate myths surrounding juvenile violence and establish an interdependency essential for the ultimate reintegration and acceptance of adolescent individuals.

If our hope is to develop successful citizens and empathetic human beings through the implicit and explicit messages of our school systems, then we first have to recapture our own empathy. We must exhibit authority that embraces both forgiveness and condemnation. Otherwise, the uncompromising severity that has allowed us to place our children in jeopardy will continue to exacerbate the problem it was intended to address: alienated, unremorseful, and uncontrollable youth. 
